\title{
Summary Appraisals of the Nation's Ground-water Resources-lower Colorado region
}

GEOLOGICAL SURVEY PROFESSIONAL PAPER 813-R

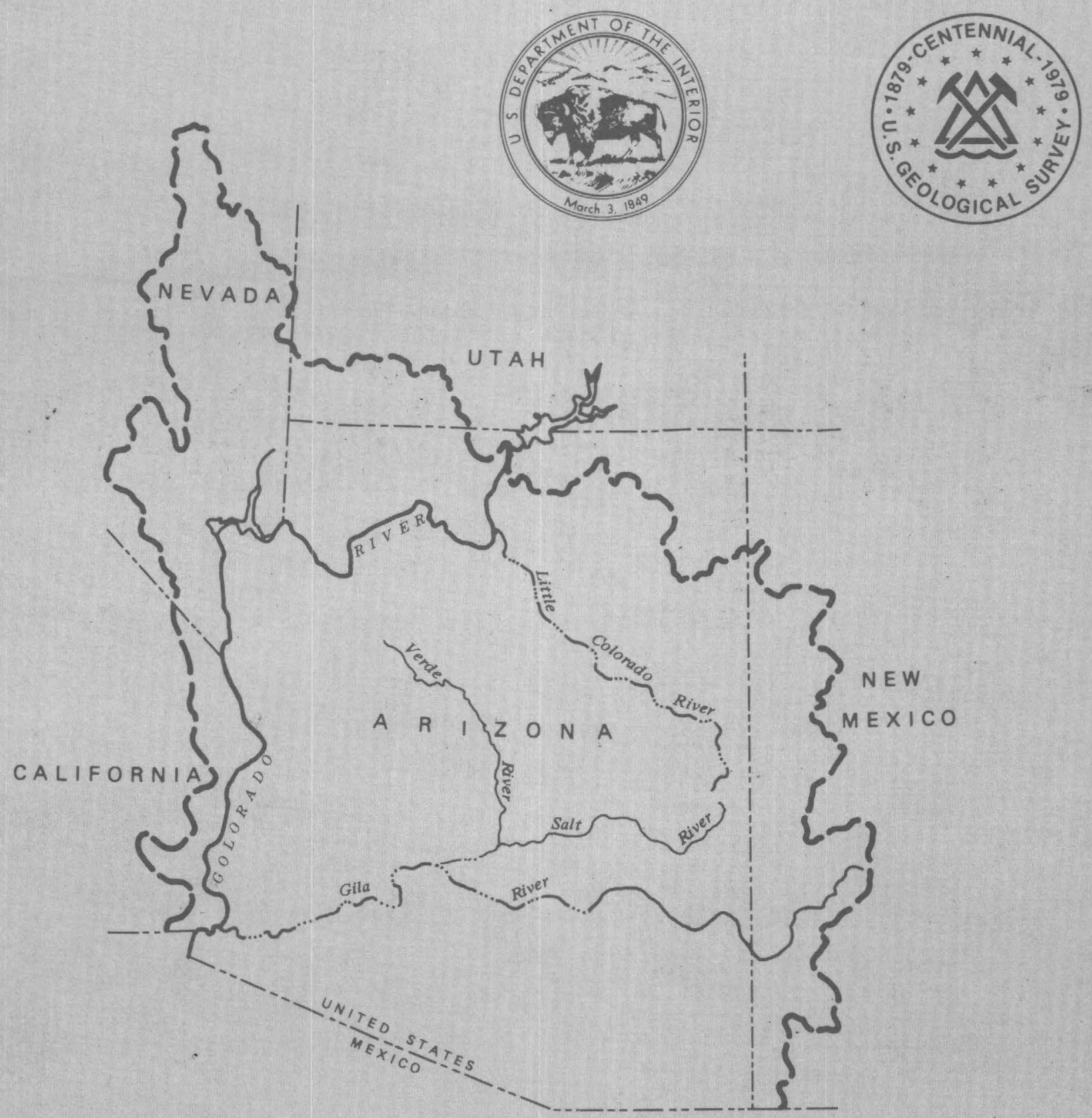



SUMMARY APPRAISALS OF THE NATION'S GROUND-WATER RESOURCESLOWER COLORADO REGION 


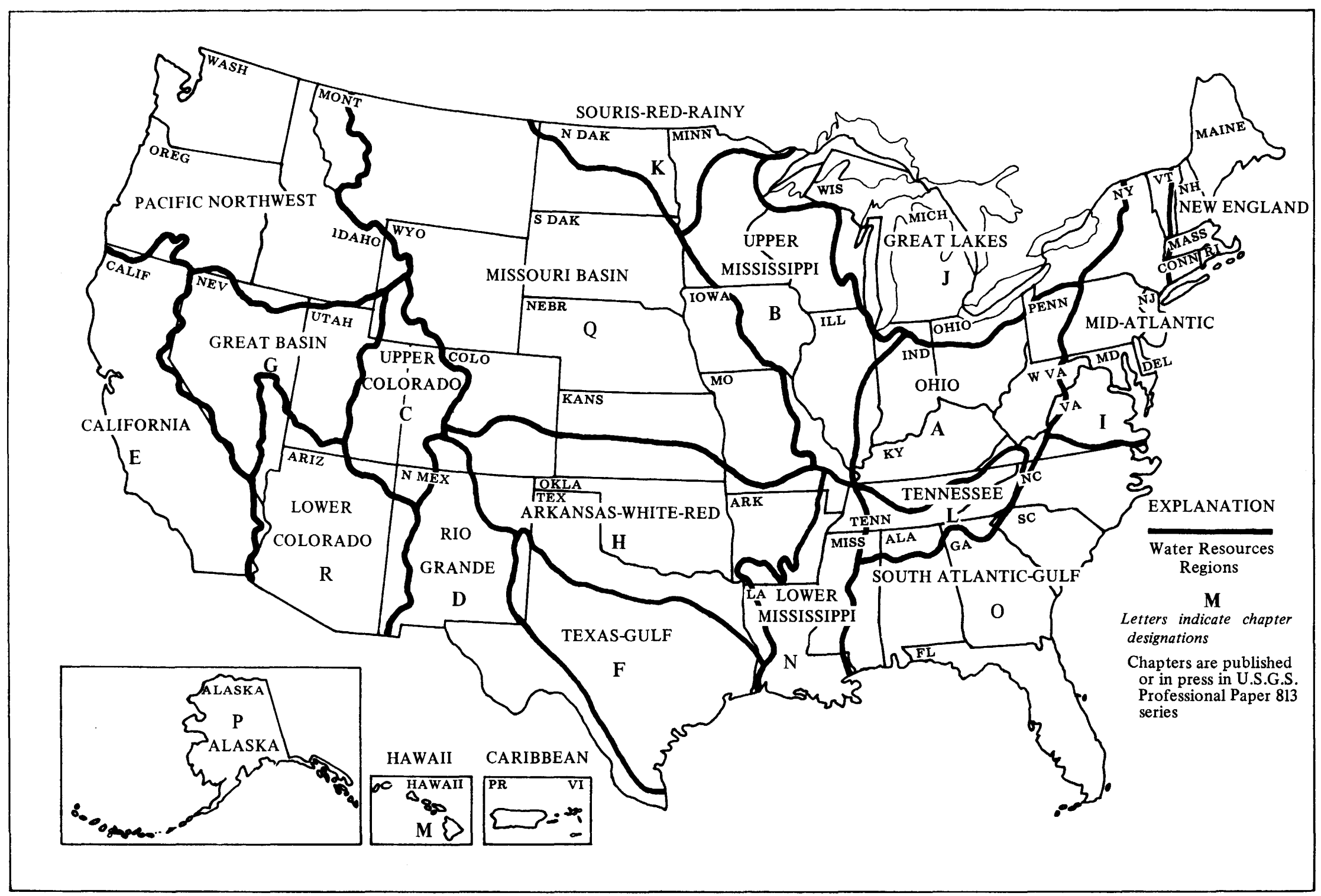

Geographic Index to the Series, U.S. Geological Survey Professional Paper 813, Summary Appraisals of the Nations Ground-Water Resources. Boundaries shown are those established by the United States Water-Resources Council for Water-Resources Regions in the United States. 


\title{
Summary Appraisals of the Nation's Ground-water \\ Resources-lower Colorado region
}

\author{
By E. S. DAVIDSON
}

GE OLOGICAL SURVEY PROFESSIONAL PAPER 813-R

A general summary of ground-water availability and the potential for greater development or extension through more efficiencies of use

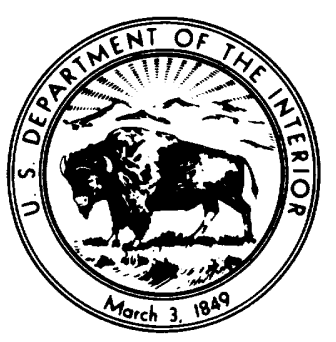




\section{UNITED STATES DEPARTMENT OF THE INTERIOR}

CECIL D. ANDRUS, Secretary

\section{GEOLOGICAL SURVEY}

H. William Menard, Director

\footnotetext{
Library of Congress Cataloging in Publication Data

Davidson, Edward Sheldon, 1926-

Summary appraisals of the nation's ground-water resources-lower Colorado region.

(Geological Survey Professional Paper; 813-R)

Bibliography: p. R21-R23.

1. Water, Underground-Colorado River watershed. 2. Water useColorado River watershed. I. Title. II. Series: United States. Geological Survey. Professional Paper; 813-R TD225.C665D38 333.9'1'04097913

$78-15608$
}

For sale by the Superintendent of Documents, U.S. Government Printing Office Washington, D.C. 20402

Stock number 024-001-03237-6 


\section{CONTENTS}

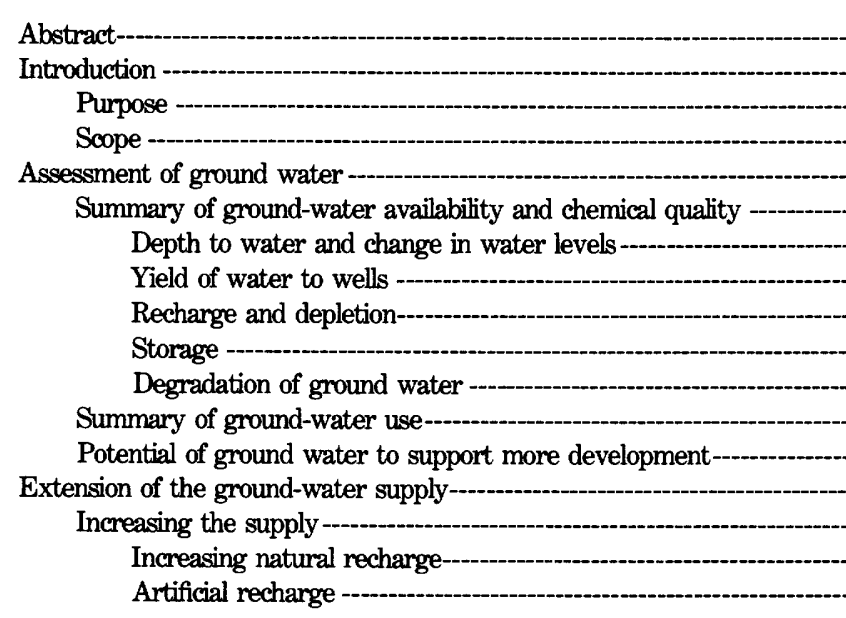

\begin{tabular}{r|} 
Page \\
R1
\end{tabular}

1

1

4

4

6

7

8

8

8
10
10

10

11
13

14
14

14

14
15

Extension of the ground-water supply-Continued

Increasing the supply-Continued

Watershed management-increasing runoff and

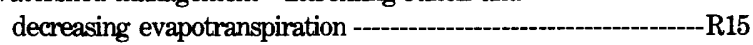

Increasing the efficiency in use of water - 16

Crop irrigation -

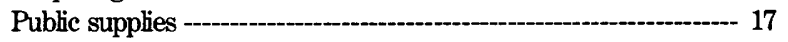

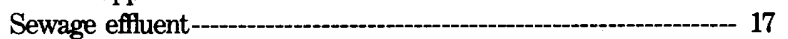

Industrial uses - --- 18

Potential use of saline water--_-_-_-_- 18

Concepts of ground-water use - 19

Mining--.-- 19

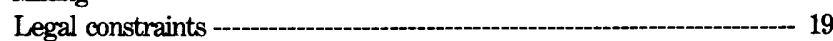

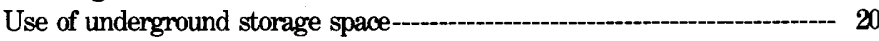

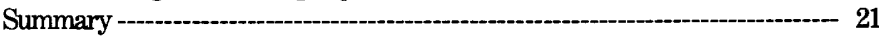

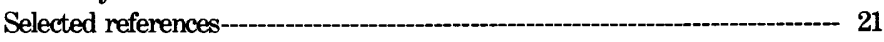

\section{ILLUSTRATIONS}

FronTISPIECE. Ground-water regions of the United States.

PLATE 1. Generalized geohydrologic framework in the lower Colorado region

2. Generalized distribution of dissolved solids in ground water, lower Colorado region -

In pocket

3. Generalized depth to water in wells tapping aquifers in the lower Colorado region -

Figures 1-5. Maps showing:

1. Water provinces and subregions in the lower Colorado region -

2. Climatic data for the lower Colorado region-

3. Normal annual precipitation in the lower Colorado region .... 5

4. Graph showing estimated annual pumpage in Arizona from prior to 1915 to 1975

5. Diagram showing major uses of ground water pumped in the lower Colorado region in 1975

\section{TABLES}

Page

TABLE 1. Estimated volume of recoverable ground water in storage in the main alhuvial aquifers in the lower Colorado region--

2. Estimated ground-water pumpage by subregion and use in the lower Colorado region, 1975

3. Projections of annual water depletion in Arizona--

\section{CONVERSION FACTORS}

The following factors may be used to convert the U.S. customary units to metric units.

\begin{tabular}{|c|c|}
\hline Multiply U.S. customary unit & $B y$ \\
\hline inch (in.) ---.- & 25.4 \\
\hline oot $(\mathrm{ft})$ & .3048 \\
\hline . & .4047 \\
\hline $\mathrm{e}\left(\mathrm{mi}^{2}\right)-$ & 2.590 \\
\hline $\begin{array}{l}\text { gallon per minute }(\mathrm{gal} / \mathrm{min}) \\
\text { acre-foot }(\mathrm{acre}-\mathrm{ft})\end{array}$ & $\begin{array}{l}.06309 \\
.001233\end{array}$ \\
\hline
\end{tabular}

To obtain metric unit

millimeter $(\mathrm{mm})$

meter $(m)$

hectare (ha)

square kilometer $\left(\mathrm{km}^{2}\right)$

liter per second $(\mathrm{L} / \mathrm{s})$

cubic hectometer $\left(\mathrm{hm}^{3}\right)$ 



\title{
SUMMARY APPRAISALS OF THE NATION'S GROUND-WATER RESOURCES-LOWER COLORADO REGION
}

\author{
By E. S. Davidson
}

\begin{abstract}
This report summarizes ground-water availability in the lower Colorado region and discusses the potential for greater ground-water development and increased efficiency of water use.

The climate in the most highly developed southwestern part of the region is warm and dry and that in the northeastern part is cool and moist to dry. Although the regional average annual precipitation is only about 14 inches and most streambeds are dry during most of the year, about 1.5 billion acre-feet of ground water of moderate to good chemical quality is stored in aquifers of the region. Much of the water use is founded on pumped withdrawal of ground water. However, in most of the southwestern part of the region pumpage and consumptive use are in excess of replenishment, resulting in declining water levels. In the southwestern part of the region, water levels generally are from 200-500 feet below land surface and in large areas are less than 200 feet. Large-diameter water wells in this part of the region commonly produce $500-1,500$ gallons per minute of water. In the northeastern part of the region, water levels generally are more than 500 feet below land surface, but in some large areas water levels are from 200-500 feet, and locally are less than 200 feet below the surface. In the northeastern part of the region, water wells generally have lower yields than those to the southwest. The yields range from a few to 2,000 gallons per minute, but most wells yield from 10 to less than 500 gallons per minute. In the southwestern part of the region about 1 billion acre-feet of ground water is recoverable from storage from the water table to a depth of 700 feet below the land surface. In the northeast about 150 million acre-feet can be recovered by dewatering a 100 -foot-thick section of a typical aquifer (16 million-acre area). The estimated current annual rate of ground-water depletion, occurring almost entirely in the southwestern part of the region, is 2.4-3.2 million acre-feet per year. Almost 6 million acre-feet is pumped each year-about 90 percent for agriculture, 6 percent for public supply, and 3 percent for industrial use. The percentage of use for public supply and industry is increasing each year.
\end{abstract}

The potential for greater development of ground water in the southwestern part of the region is constrained by land subsidence, earth cracks, increasing costs of pumping and transportation, and moderate to poor chemical quality of water. More ground water can be developed in the northeastern part of the region, where the major constraint is pumping cost owing to low to moderate well yields and depth to water. Some benefits can be realized everywhere in the region through changes in current use and greater efficiencies of use. Additional supplies may be made available by capture of natural evapotranspiration. Increasing the efficiency of use is possible hydrologically but, in the near term, is more expensive than increasing groundwater development. Decrease of irrigation, change to water-saving methods of irrigation, use of saline water, decrease of per capita public-supply use, and more reuse of water in almost every type of use could help extend the supply and thereby reduce the current rate of ground-water depletion. Financial problems have not yet caused an overall decrease in pumpage, but, locally, operating costs or partial dewatering of the aquifer has eliminated or decreased withdrawal. Current water laws in all States of the region, except Arizona, control or allocate the use of ground water.

\section{INTROIUCTION}

The lower Colorado region is in the semiarid to arid Southwestern United States and comprises most of Arizona and adjacent small parts of California, Nevada, New Mexico, and Utah (fig:. 1). The region has been divided into three socioeconomic subregions for planning purposes, and the socioeconomic subregions are superimposed on the water provinces (fig. 1). In general, the region is the Colorado River drainage basin downstream from Lees Ferry, Ariz. The Colorado River and the tributary Little Colorado, Virgin, and Gila Rivers and their tributaries drain most of the region. A few basins are drained internally, and srnall areas in the south and southeast drain directly southward into Mexico and the Gulf of California. The total drainage area of the lower Colorado River upstream from the Mexican border near Yuma is about $135,000 \mathrm{mi}^{2}$, of which about $114,000 \mathrm{mi}^{2}$ is in Arizona.

The Southwestern part of the region generally is warm to hot (fig. 2), and rainfall and cloud cover are sparse. Owing partly to air-conditioning, population growth since 1950 makes it one of the fastest growing areas in the Nation. The central and northeastern parts are cool to warm and receive from 8 to about 40 in. per year of rainfall. The population of the region in 1975 was between about 2.5 and 3 million. The growing season in much of the southwestern part of the region is very long, and two or three crops can be harvested from one plot during the year. However, precipitation is insufficient to mature crops, necessitating irrigation with surface water and pumped ground water.

The economy of Arizona and the Las Vegas, Nev., area dominate the economy of the region. The major sources of income in Arizona are from agricultural production, 21 percent; manufacturing, mainly light indus- 


\section{EXPLANATION}

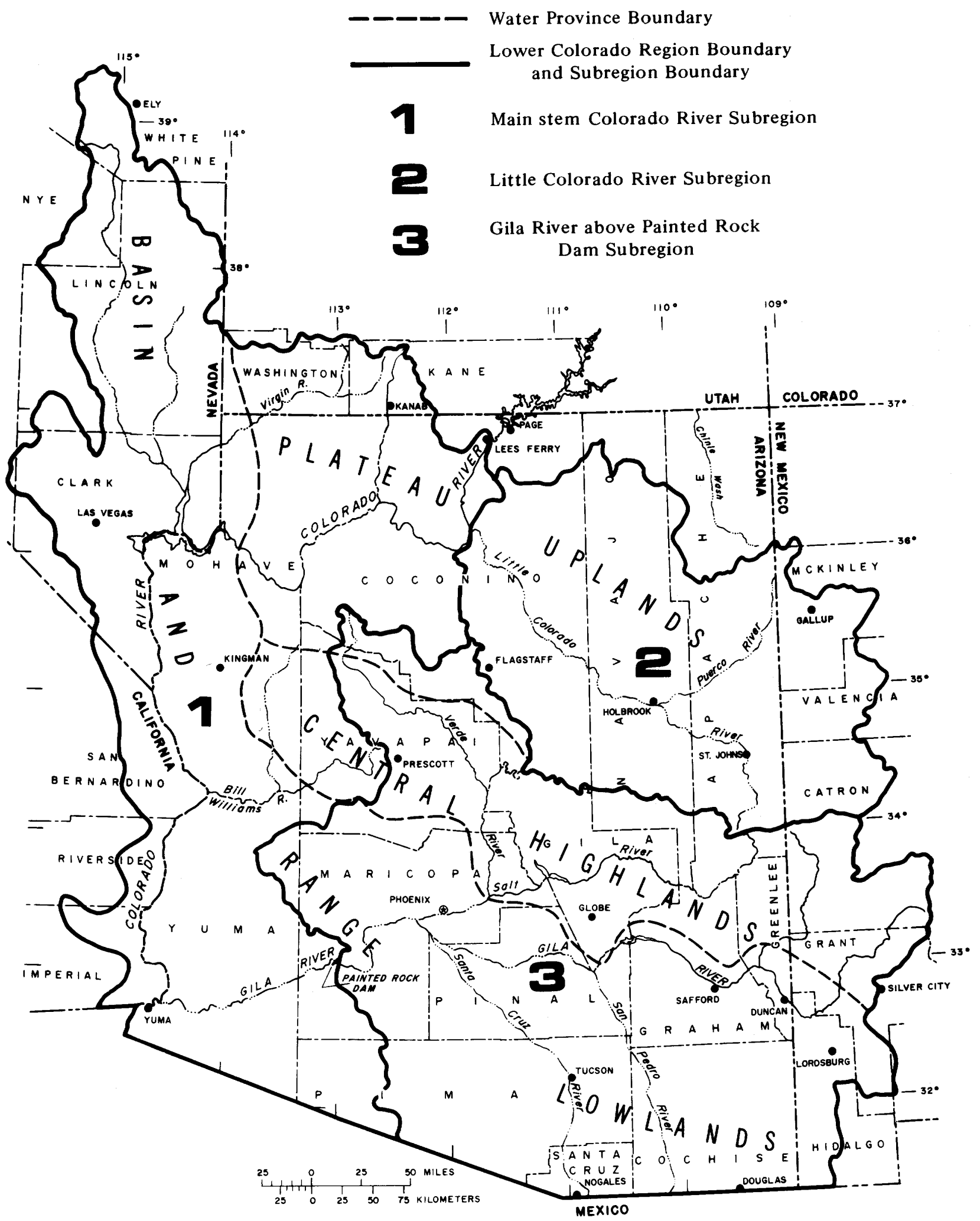

FIGURE 1.-Water provinces and subregions in the lower Colorado region. 


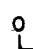

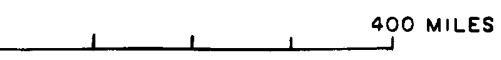

Modified from Pacific Southwest Interagency Committee (1971b, fig. 1)

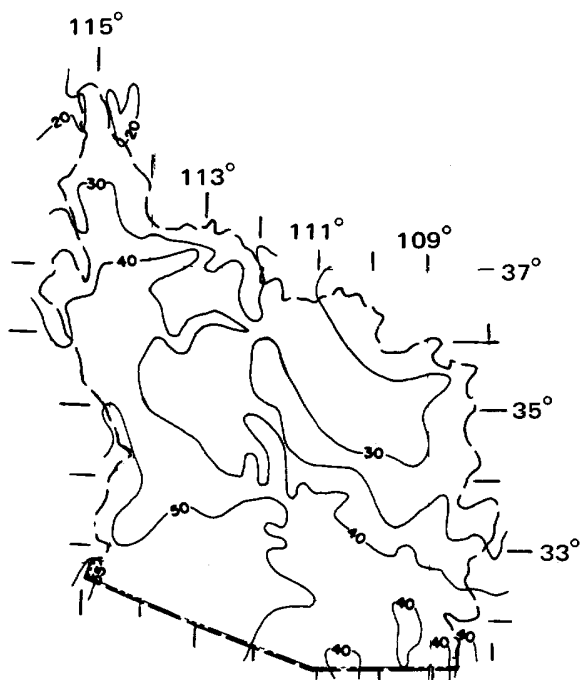

DAILY AVERAGE TEMPERATURE, JANUARY

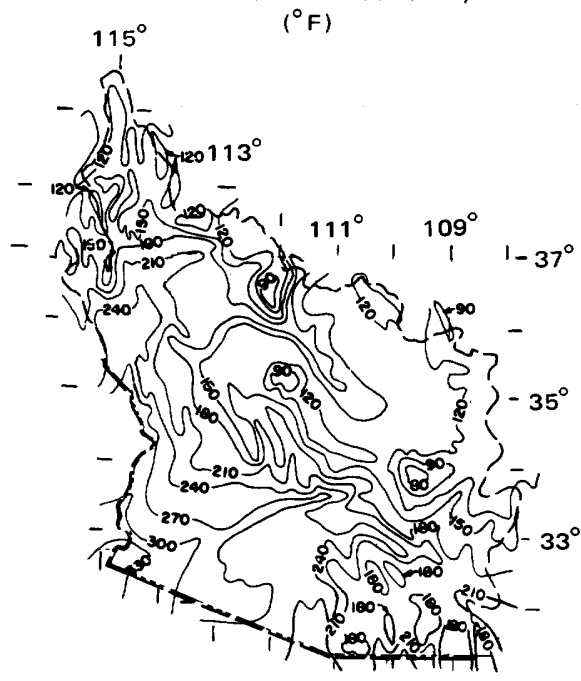

MEAN LENGTH OF FROST-FREE PERIOD (DAYS) BETWEEN LAST $32^{\circ} \mathrm{F}$ TEMPERATURE IN SPRING AND FIRST $32^{\circ} \mathrm{F}$ TEMPERATURE IN AUTUMN

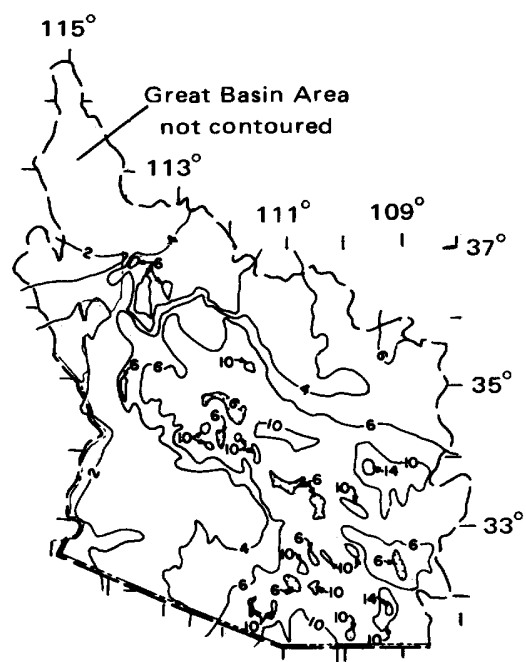

NORMAL MAY-SEPT. PRECIPITATION

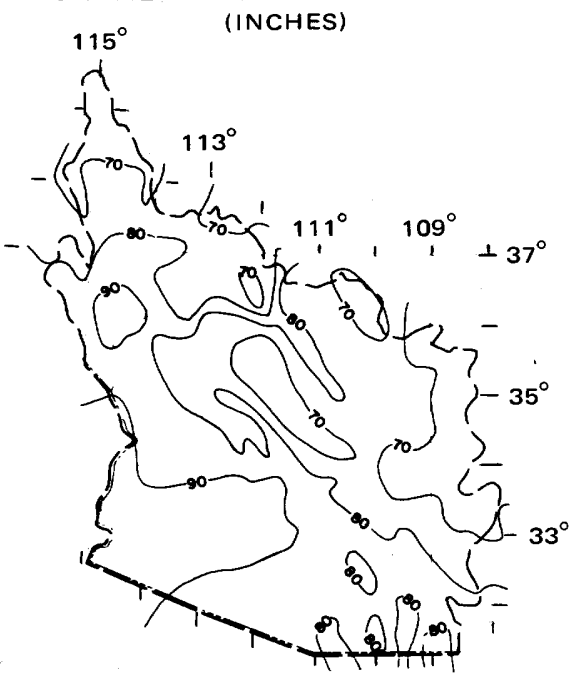

DAILY AVERAGE TEMPERATURE, JULY

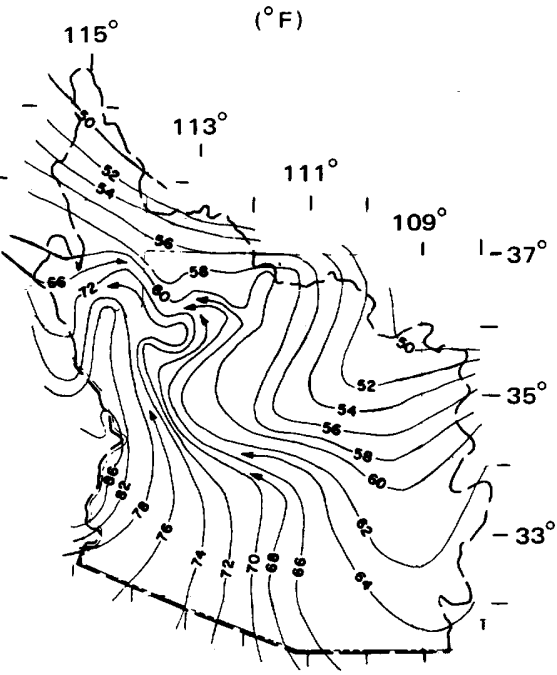

MEAN ANNUAL LAKE EVAPORATION (INCHES)

FIGURE 2.-Climatic data for the lower Colorado region. 
try and high-technology industry, 41 percent; mining, 25 percent; and tourism, 13 percent (Valley National Bank of Arizona, 1975). The total income from these sources is about $\$ 5 \frac{1}{4}$ billion per year.

Crops generate about 40 percent of the total agricultural income, and crop production is the largest consumer of water in the region. Consumption for public supply and mining is significant, and production of electrical energy is becoming a significant water-consuming industry.

\section{PURPOSE}

The purpose of this report is to describe the utility of ground water in the lower Colorado region in a format useful to administrators and policymakers who have the responsiblity of water-resource development or management. In much of the Nation, ground water is a littleutilized resource, and discussion of its utility is more pertinent nationally than in the semiarid Southwest, where ground water has long been utilized and is overdeveloped in many areas. However, alternative schemes for use and the potential deleterious effect of overuse need to be examined; discussion of these factors is the principal purpose of this report.

\section{SCOPE}

Ground water availability, use, depletion, potential for greater development and management options are summarized in this report. Basic ground water occurrence information, such as ground water chemical quality, recoverable quantities of water in storage and potential aquifer yields also are summarized. Included also is a discussion of the use of underground space for storage of miscellaneous fluids, such as natural gas and liquid toxic or radioactive wastes. The data presented are taken from many comprehensive reports, which are referenced at the end of this paper. Not all necessary ground-water information can be easily measured, and calculations, such as those for recharge and depletion, that seriously affect water administration and planning are briefly described.

Although the main emphasis in this report is on the potential usefulness of the ground-water supply, how the supply can be managed, and the negative factors that might result from increased use of ground water, effective and efficient use of the supply is complicated more often by legal problems and by public sentiment and opinion than by technical considerations. Therefore, schemes that are technically possible or even technically desirable frequently prove impossible to implement because of other considerations. Nevertheless, these other factors change more rapidly in time than do physical conditions and technical analyses. Accordingly, the report contains no more than passing reference to the sociologic or economic factors that may impact on the wise use of the resource.

\section{ASSESSMENT OF GROUND WATER}

The lower Colorado region comprises three water provinces, which have major differences in geology, physiography, altitude, climate, and availability and use of ground water. These water provinces are: The Basin and Range lowlands province in the southern and western parts of the region; the Plateau uplands province in the northeastern part of the region; and the Central highlands province, a transitional zone between the other two provinces (fig. 1). Ground-water use and storage calculations are presented for the socioeconomic subregions that overlap the water provinces.

The Basin and Range lowlands province contains most of the population, is most intensively developed, and is characterized by north- to northwestward-trending broad and gently sloping basins that surround and separate steep and rugged mountains. The basin surfaces are at altitudes of $100-4,500 \mathrm{ft}$ above mean sea level, and the ranges crest from 1,000 to $4,000 \mathrm{ft}$ higher. The average annual precipitation ranges from a low of $3 \mathrm{in}$. near Yuma to 35 in. in mountainous areas (fig. 3; Green and Sellers, 1964). Because of the latitude, altitude, and physiography, the lowlands is the warmest province; it has the longest growing season, the most available water, and more land suitable for agriculture than the other two provinces.

The sparsely settled Plateau uplands province is characterized by plateaus, canyons, buttes, and mesas and contains a few dispersed volcanic mountains. Most of the province is $5,000-7,000 \mathrm{ft}$ above mean sea level; the canyons are as low as $4,000 \mathrm{ft}$ and the highest peaks are about 13,000 ft above sea level. Average annual precipitation ranges from 6 in. to 30 in. (fig. 3; Green and Sellers, 1964). The climate is cooler and the growing season shorter than in the Basin and Range lowlands (fig. 2); the land is not as suitable for farming, either because of topography or lack of sufficient quantity or usable quality of water. Ranching and recreation are the dominant land uses.

The Central highlands province is mountainous and very sparsely settled. The topography is precipitous, and the altitude ranges from 2,500 to $11,000 \mathrm{ft}$ above mean sea level. Because of the mountainous terrain, the highlands are cool and receive the most precipitation. Precipitation ranges from 16 to 40 in. per year (fig. 3; Green and Sellers, 1964). Much of the streamflow used in the adjacent lowlands and uplands provinces originates in this province. Ranching, recreation, and mining are the dominant land uses. 


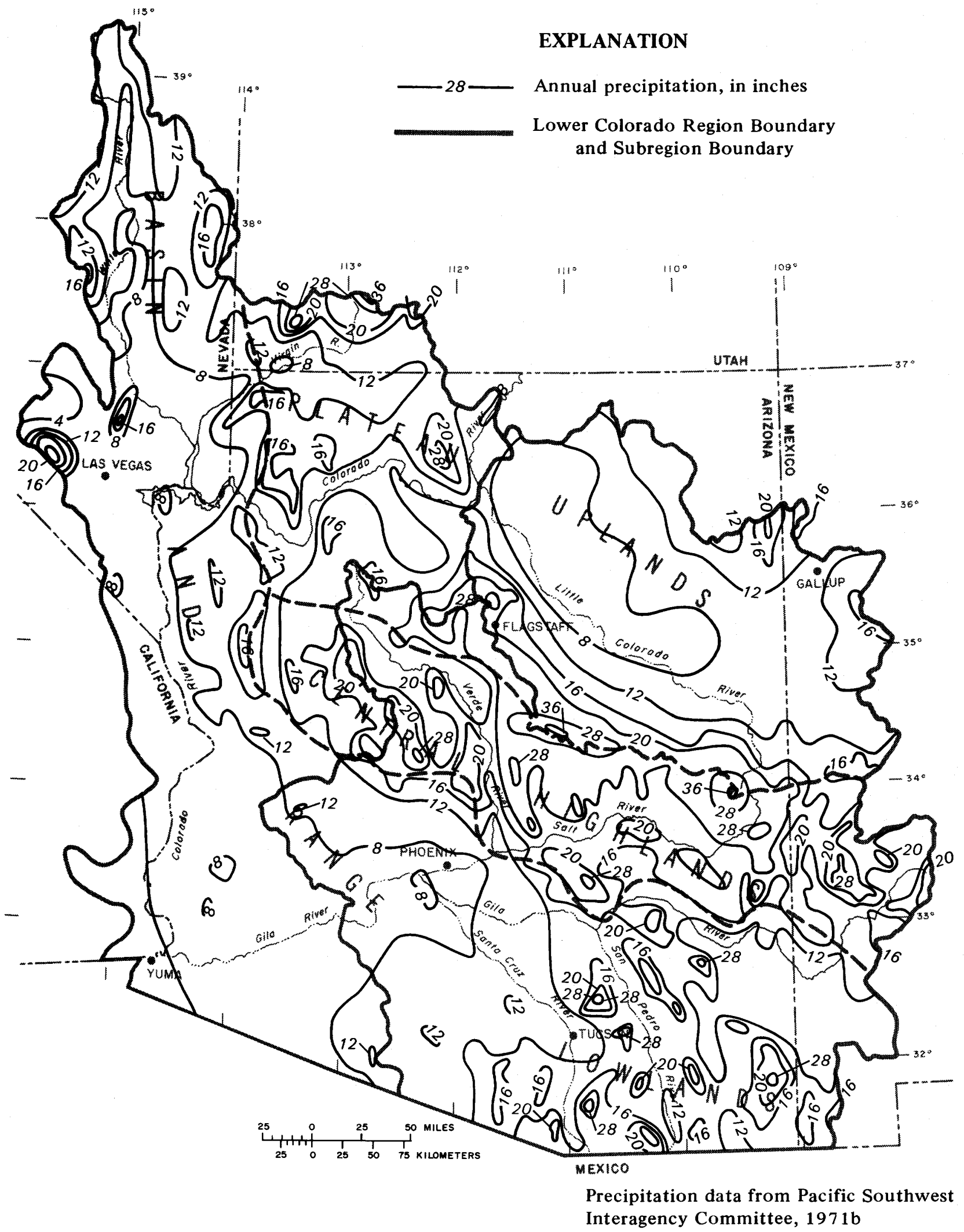

Figure 3.-Normal annual precipitation in the lower Colorado region. 


\section{SUMMARY OF GROUND-WATER AVAILABILITY AND CHEMICAL QUALITY}

The Basin and Range lowlands province contains extensive highly developed aquifers (pl. 1), which store vast quantities of good-quality water that can be pumped at rates sufficient for economic irrigated agriculture. In addition, large quantities of streamflow are stored in reservoirs and used for agriculture. The total consumptive use of ground water is greater than the renewal of the supply, thus causing a steady decline of water levels in the aquifers.

The extensive thick sediment that fills the basins are the aquifers into which precipitation and streamflow infiltrate and are stored as ground water. The basins are filled to depths of 5,000 to at least $10,000 \mathrm{ft}$ with discrete layers to poorly sorted deposits of clay, silt, sand and gravel. The mountains contain only small amounts of ground water; however, precipitation increases in direct proportion to altitude, and a substantial part of the water recharged to the aquifers originates as runoff of precipitation from mountainous terrain. The mountains in Arizona and New Mexico are composed of granitic, volcanic, and some sedimentary rocks. In Nevada, many of the ranges are limestone and associated sedimentary rocks.

In general, the coarser material in the basins is found near the mountains, and fine-grained material is deposited along along the axes and in the deeper parts of the basins. Volcanic rocks and evaporite deposits are interbedded with the clastic sediment in many basins. Most of these deposits are weakly to moderately consolidated, and the more deeply buried deposits are the more strongly cemented. Unconsolidated sand and gravel occur along streams and as a blanketing deposit; some are being deposited at the present time by active streams (Cooley and Davidson, 1963).

The more permeable sand and gravel beds in the uppermost parts of the basins are the most extensively developed sources of ground water; saturated and permeable sand and gravel beds along stream channels or in blanketing deposits yield the greatest amount of water to wells, but the vast quantity of underlying thick sediment stores the greatest volume of water. In most basins, the water-yielding beds are hydraulically connected and the contained water is unconfined at shallow depths; however, in some places, and generally as depth increases, water-bearing beds are more completely separated by the less permeable beds, and semiconfined artesian conditions prevail.

The chemical quality of most ground water is suitable for most purposes, either with no beneficiation or with minor treatment, such as softening. The dissolved-solids concentrations range from less than 100 to more than
$100,000 \mathrm{mg} / \mathrm{L}$ and generally are less than $1,000 \mathrm{mg} / \mathrm{L}$. Ground water that contains more than $1,000 \mathrm{mg} / \mathrm{L}$ dissolved solids occurs mainly along and near the Gila River from Safford to Yuma, Ariz.; along the southernmost reach of the Colorado River; in the southeastern part of Nevada; and near Wilcox, Casa Grande, and Tucson (pl. 2). The dissolved-solids concentrations in ground water differ areally and with depth owing to differences in the chemical character of the aquifers. For example, 1,000ft-deep wells in the Casa Grande area penetrate mainly sand and gravel and minor thicknesses of gypsum and salty clay. Studies of water in these wells show that significant amounts of dissolved solids originate near the gypsum and salty beds. Because many wells in the region are open to the entire section of sedimentary deposits penetrated by the well, poor-quality water from such beds is mixed with better-quality water and the final well-discharge product may be so poor as to make the water nearly unusable. Additionally, because of such well construction, ground water having high concentrations of dissolved solids may migrate through the well and into other parts of the aquifer, thereby contaminating ground water formerly of good quality.

Generally because of increased residence time or because of greater opportunity for ground water to pass through and dissolve chemicals from the enclosing rocks, ground water at depth contains more dissolved solids than that nearer the surface. In some places, the concentration decreases with depth concurrent with a change in water type. In the Willcox and Tucson areas, in Pinal County, and in the Beardsley area of northwest Maricopa County, Ariz., the water grades with increasing depth from a calcium bicarbonate to a sodium bicarbonate type (Kister, 1973). Near Tucson, ground water shows a decrease in calcium relative to sodium with increasing depth, and water at a depth of $2,000 \mathrm{ft}$ contains less dissolved solids than ground water nearer the surface (Kister, 1973; Laney, 1972).

The chemical quality of ground water contained in rocks of the mountain blocks generally is similar to that of precipitation and surface flow and contains a lower concentration of dissolved solids than ground water in the sedimentary rocks of the basins. The dissolved-solids concentrations generally are less than $1,000 \mathrm{mg} / \mathrm{L}$. However, well yields are small compared with those in aquifers of the basin, and generally wells in mountainous areas are adequate only for individual domestic or stock supplies.

The Plateau uplands province is underlain chiefly by consolidated sedimentary rocks, which consist mainly of sandstone, siltstone, claystone, and limestone. The sandstone and limestone form the chief aquifers in the area (pl. 2); the siltstone and claystone are nearly imperme- 
able and form confining beds throughout most of the area. Where water-bearing beds of sandstone and limestone alternate with the confining beds, the water in the aquifers is under artesian pressure. Sand and gravel deposits along major streams form isolated "shoestring" aquifers of limited areal extent. The water in the "shoestring" aquifers is unconfined. The quantity and chemical quality of water are dependent mainly on precipitation and streamflow, but in some places these aquifers are supplied by ground water discharging from the underlying consolidated sedimentary rocks. Ground water generally can be produced in the eastern part of the uplands, but adequate supplies are not easily available in the western part (pl. 2). Despite the large amount of ground water available in the eastern part, low well yields and poor to fair chemical quality of water restrict its use (McGavock and Edmonds, 1974).

The dissolved-solids concentrations in ground water in the rocks of the uplands range from 90 to more than $60,000 \mathrm{mg} / \mathrm{L}$ (Kister, 1973). Ground water in the $\mathrm{N}$ and $\mathrm{C}$ aquifers contains the least dissolved solids (pls. 1 and 2). The greatest concentrations are in ground water in the Black Mesa area and in aquifers along the Zuni River and the lower reach of the Little Colorado River (pl. 2). Although gradation between chemical types of ground water is common, most water with less than $500 \mathrm{mg} / \mathrm{L}$ of dissolved solids is a calcium or sodium bicarbonate type, and most with more than $500 \mathrm{mg} / \mathrm{L}$ is a sodium or calcium sulfate or sodium chloride type. Very highly mineralized water, however, commonly is a bicarbonate sulfate type (Kister, 1973).

The Central highlands province is similar geologically to the Basin and Range lowlands except that the mountains dominate the adjacent basins. Crystalline igneous and metamorphic rocks form much of the Central highlands; they do not store large amounts of ground water per unit area. Small amounts of ground water can be obtained from fractures in these rocks and from the thin sand and gravel deposits along streams that drain the mountainous terrain. Where geologic conditions are favorable in the highlands province, extensive bedded deposits of volcanic rocks and some of the few sedimentfilled basins store and yield large amounts of water; the greatest water production is obtained from wells tapping these rocks.

Ground water draining from the rocks in and near the Central highlands is the source of perennial flow in the Gila, Salt, and Verde Rivers. The dissolved-solids concentration of the water generally is less than $1,000 \mathrm{mg} /$ $\mathrm{L}$; however, several springs yield saline water. Clifton Hot Springs yield sodium chloride type water containing more than $9,000 \mathrm{mg} / \mathrm{L}$ dissolved solids to the San Francisco River (Kister, 1973; pl. 2). Springs along the Salt
River yield sodium-chloride type water that contains more than $37,000 \mathrm{mg} / \mathrm{L}$ dissolved solids, and springs on the tributary White River yield sodium chloride water that contains more than $8,000 \mathrm{mg} / \mathrm{L}$ dissolved solids.

\section{DEPTH TO WATER AND CHANGE IN WATER LEVELS}

The depth to water in a well directly affects the cost of producing ground water from that well; if the depth to water increases over time, the cost of production also increases, and eventually the increased cost may restrict the use. In most of the lower Colorado region, ground water is mined or removed from storage. In a few places, mostly along perennial streams, infiltration of streamflow is sufficient to replace the water withdrawn, and there is no long-term removal from storage or decline in water level. In these places water levels decline in response to withdrawal and rise during a wet season or in response to a decrease in pumped withdrawal.

In much of the region ground water is pumped from storage in excess of replacement, and the pumping depth to water increases in direct proportion to the volume of water pumped and the physical character of the aquifer. The most severe water-level declines are in the extensively developed Basin and Range lowlands province. Here, as water levels decline, the rate of decline commonly increases even though the pumping rate is held constant, because the aquifers tend to be more firmly cemented and less porous and permeable with depth. This combination of water-level lowering caused by removal of water from storage and the increased rate of lowering per unit of production tends to increase the cost of pumping at a geometric rather than arithmetic rate. In addition, the currently increasing cost of energy is accelerating the increase in cost of pumping. Incidence of land subsidence and earth cracks that are related to water-level decline also are a factor in the total cost of continued ground-water depletion. These hazards are relatively minor now, but increased ground-water decline probably will increase the cost to mitigate the damage attributable to subsidence.

To compare water-level changes from one year to another, the depth to water usually is measured just prior to the pumping season when water levels have recovered or nearly recovered to a uniform or virtually nonchanging level. This is called the "static" water level, even though the levels are known to be constantly changing with time. The water levels under pumping conditions generally are 100-150 ft lower than static levels in areas where large-capacity wells are producing in the range of $1,000-1,500 \mathrm{gal} / \mathrm{min}$. The following discussion of depth to ground water and change in water level refers to the static water level.

In most of the Basin and Range lowlands province, the 
depth to water in 1975 (pl. 3) was less than $500 \mathrm{ft}$ below the land surface, and in a large part of the area the depth to water was less than $200 \mathrm{ft}$. Water levels are shallowest along the major stream channels in the lowest parts of the basins. In a few areas, the water level is at or very near the surface, and some wells that tap artesian aquifers flow. In heavily pumped areas, the maximum annual declines are as great as $10 \mathrm{ft}$ and commonly range from 2 to $6 \mathrm{ft}$ (Brown, 1976, sheet 2; Babcock, 1976, sheet 2). Water-level declines since pumping started in the early 1920 's generally are greater than $150 \mathrm{ft}$ in most moderately to heavily pumped areas and locally are as great as $400 \mathrm{ft}$. Land subsidence of inches to about 10 feet has accompanied withdrawal of ground water in much of central Arizona and in the Las Vegas area in Nevada. The volume of subsidence may be from 5 percent to slightly more than 30 percent of the volume of water withdrawn. In the basins, subsidence is accompanied by earth cracks or fissures, inches to feet wide and tens of feet to many miles long. The land on either side of some cracks is vertically displaced as much as $3 \mathrm{ft}$. The cracks present a hazard to highways, railroads, pipelines, buildings, etc. Some potential locales for earth cracks have been identified, but generally, potential fissure locales cannot yet be accurately predicted.

In the Plateau uplands province, the depth to water is greater than $500 \mathrm{ft}$ in much of the area and is less than $200 \mathrm{ft}$ mainly along the Little Colorado and tributary Puerco and Zuni Rivers (pl. 3). Near Flagstaff, Ariz., the depth to water in municipal wells is $1,100-1,300 \mathrm{ft}$ below the land surface and to the west is as great as $2,840 \mathrm{ft}$ (Babcock, 1976, sheet 2). Because withdrawal in the uplands does not generally exceed recharge, water levels generally show no decline. Declines of about $2 \mathrm{ft}$ per year have occurred in small areas near Snowflake, Ariz., and along the Little Colorado River northeast of Snowflake.

In the mountainous areas of the Central highlands province, water levels in wells range from a few tens to about $300 \mathrm{ft}$ below the land surface. In the parts of the area underlain by volcanic rocks, depths to water are from a few feet along major streams to more than 500 $\mathrm{ft}$ elsewhere. In the few sediment-filled basins, the water levels generally are less than $200 \mathrm{ft}$ below land surface along streams and deeper away from the streams. Any change in water levels in this province generally is temporary because of ample recharge, except for a few areas where water levels decline about 1-2 ft per year (Brown, 1976, sheet 2; Babcock, 1976, sheet 2).

\section{YIELD OF WATER TO WELLS}

The greatest yield of water to wells in the lower Colorado region is in the Basin and Range lowlands province
(Brown, 1976, sheet 3; Babcock, 1976, sheet 2). Largediameter water wells tapping the permeable sand and gravel beds in the basins and along the Colorado River are capable of yielding more than $2,500 \mathrm{gal} / \mathrm{min}$, although most wells in the basins are pumped at 500 to $1,500 \mathrm{gal} / \mathrm{min}$. In the mountainous parts of the province, well yields generally are less than $100 \mathrm{gal} / \mathrm{min}$ and commonly are less than $10 \mathrm{gal} / \mathrm{min}$.

The major aquifers of the Plateau uplands are capable of yielding at least $10 \mathrm{gal} / \mathrm{min}$ of water to wells, and locally irrigation wells produce as much as $2,000 \mathrm{gal} / \mathrm{min}$. Wells in the sand and gravel beds along streams generally can produce $100 \mathrm{gal} / \mathrm{min}$ or more from shallow depths. In contrast, wells tapping the sandstone and limestone aquifers generally must be $500-1,000 \mathrm{ft}$ deep to produce the same yield. In some areas it may be possible to produce, at high cost, good-quality water from depths of thousands of feet, but the deeper units have not yet been adequately prospected.

In the Central highlands province, well yields generally range from about $10 \mathrm{gal} / \mathrm{min}$ in the mountainous areas to $1,000 \mathrm{gal} / \mathrm{min}$ in places along streams or where wells are in thick saturated sediment or volcanic rock.

\section{RECHARGE AND DEPLETION}

Recharge is that part of precipitation that eventually reaches and is stored in the ground-water reservoir. Such factors as the permeability of near-surface materials, configuration of the land surface, intensity and distribution of precipitation, areal extent of the aquifer, volume of streamflow, amount and type of land cover, and potential for evaporation of water from the land surface control modify the amount of precipitation that ultimately may become ground-water recharge. Modification of the water regime in an area by ground-water withdrawal, removal of riparian growth, dam construction, or removal of gravel from the streambed may have a substantial effect on recharge. These factors may either increase or decrease recharge. If recharge is increased, the increase may be at the expense of the natural loss to evaporation and transpiration, making more of the original precipitation available for man's use.

The effect of these factors in the lower Colorado region is substantial, but it is so variable in space and time that the amount of recharge in most places can only be estimated crudely. In most studies of aquifers in the region, recharge is estimated indirectly by evaluating the ground-water budget in the study area. About 100 million acre-ft of precipitation (Pacific Southwest Interagency Committee, $1971 \mathrm{~b}$, p. 6) falls on the region annually (fig. 3), but only about 1 percent of this volume is estimated to recharge the ground-water aquifers (Ari- 
zona Westwide Study Team, 1973, p. 32).

In the lower Colorado region either recharge or depletion of storage must be estimated in order to plan effective long-term use of ground water. This is particularly true in planning use of ground water for a public supply, in which case the resource presumably should never be completely depleted unless replacement sources are available. The direct estimation of recharge is based on algebraic addition of a series of reasonable approximations, and nearly always the result must be compared with and adjusted to values derived from indirect methods. The direct method generally requires estimation of underflow, estimation of the infiltration of precipitation, measurement of infiltration of streamflow from the major streams, and estimation of infiltration from smaller streams. All these "direct" functions require knowledge of the precipitation, streamflow, and physical characteristics of the aquifer and the overlying earth. More commonly than not, such knowledge is incomplete, therefore, recharge estimates are only crudely accurate. If the ground-water discharge can be closely calculated, another method is commonly used; this method is based on the premise that over a long period of time prior to withdrawal, storage is stabilized and outflow from the aquifer is equivalent to inflow. If the surface and underground outflow of ground water can be closely calculated or measured and if the loss to evaporation and transpiration can be reasonably approximated, then the sum of the two outflow estimates may be a reasonably close estimation of recharge. Generally, this approach requires a complete knowledge of the streamflow budget in the area and is most accurate where streamflow infiltrates to the aquifer (losing streams). If the streams are fed both by ground water and by water from overland runoff (gaining streams), the estimate is more complicated and generally less accurate.

In many recent water-planning studies, recharge is ignored, and an estimate of ground-water depletion is used instead to relate both to ground-water storage and withdrawal. In this calculation, the pumpage less estimated depletion is equivalent to the sum of natural recharge and return to the aquifer of applied ground water. (Infiltration of applied surface water is here defined as recharge.) This method requires close measurement of all water used in an area, and it also requires accurate measurement and calculation of the decrease in water content of the dewatered part of the aquifer. Again, most of the volume calculations are estimates based largely on empirical solutions and the investigator's experience so the calculations are only as accurate as these two factors allow.

The basins in the Basin and Range province are re- charged by infiltration of runoff in the main stream channels, by infiltration of runoff along small streams at the mountain fronts, by infiltration of excess applied irrigation water from surface-water sources, by infiltration of surface water transported in unlined irrigation canals, by underflow from upstream basins, and possibly by a small amount of direct penetration of precipitation. It is estimated that 3-6 percent of the precipitation that falls on the mountains infiltrates the sand and gravel deposits along small streams at the mountain fronts and probably recharges the ground-water reservoir (Brown, 1976). In some areas where "saturated" conditions exist because of long-term application of irrigation water, a large part of the surface water that flows through unlined canals and some that is applied to fields infiltrate to the groundwater reservoir. In many areas, however, the amount of recharge from this source probably is negligible. In some basins the ground-water reservoir is recharged by underflow from upstream basins. The interbasin movement of ground water is recharge to the lower basin but is discharge from the upper basin.

In the Plateau uplands province, the water-bearing rocks are recharged mainly in their areas of outcrop by infiltration of runoff from precipitation and snowmelt. A smaller part of the recharge is gained from infiltration of precipitation, snowmelt, and runoff on overlying rock units. The recharge areas-mostly in the southern and eastern parts of the uplands-are generally more than $6,000 \mathrm{ft}$ above mean sea level, where the precipitation is more than 15 in. per year (fig. 3).

Most of the rocks in the Central highlands province are recharged from direct precipitation. Ground water in the few basins is recharged similarly to the basins in the Basin and Range province.

Aquifers in the lower Colorado region have not been investigated in sufficient detail to allow better than approximate estimates of the recharge. Therefore, recharge has been derived from calculations comparing pumpage, depletion, recharge, and return flow. Harshbarger and others $(1966$, p. 5,6$)$ estimated that in the late 1950 's the annual statewide pumpage was about 5 million acre-ft, of which about 1 million acre-ft was from the renewable supply (recharge), and that the annual ground-water depletion was about 4 million acre-ft. The staff of the Arizona Water Commission (1975) estimated that for normalized 1970 values the statewide annual pumpage was about 5 million acre-ft, the annual recharge was about 0.2 million acre-ft (Arizona Water Commission, table 21, p. 113-114), and annual ground-water depletion was 2.2 million acre-ft (Arizona Water Commission, p. 88). The pumpage is about the same in both periods, and the discrepancy between the two depletion and recharge calculations lies partly in estimates and 
definition of the amount of applied water that returned to the aquifer.

A study team approached the same problem for the lower Colorado region in the late 1960's (Pacific Southwest Interagency Committee, 1971b). This team concluded that information was not adequate to estimate recharge but that estimation of the depletion quantity was adequate for planning purposes. The annual pumpage was about 5 million acre-ft and the annual depletion was estimated as 2.5 million acre-ft (Pacific Southwest Interagency Committee, 1971b, p. 30) and 2.6 million acre-ft (Arizona Westwide Study Team, 1973, p. 30).

In 1975 and 1976 members of the Arizona Water Resources Division staff (S. G. Brown, written and oral commun., 1976) calculated depletion and recharge using 1972 and 1973 annual pumpage figures of almost 5 million acre-ft. They found that depletion was about 2.4-3.2 million acre-ft per year and that recharge was about 1 million acre-ft per year. Again the discrepancy with other studies is due to a smaller allowance for infiltration of applied water to the underlying aquifer. In all the above calculations, pumpage was greater than depletion and these factors were the primary estimates. The difference between pumpage and depletion was then assigned to recharge and return from applied water. Natural losses are now a minor part of the equation in heavily pumped areas; hence, natural outflow and its originating recharge supply are not included in the above calculations.

\section{STORAGE}

The alluvial aquifers in the lower Colorado region contain vast amounts of physically recoverable ground water in storage (table 1). Along the main stem of the Colorado River and in the Gila River drainage basin, about 1 billion acre-ft of ground water is estimated to be recoverable from storage in the aquifers from the water table to a depth of about $700 \mathrm{ft}$ below the land surface; in addition, about 150 million acre-ft of recoverable ground water is stored in a typical 100 -ft-thick section of aquifer in the Little Colorado River subregion of the Plateau uplands province (pl. 1). These large quantities are in marked contrast to the usable capacity of the principal surface-water reservoirs; their capacity is 32 million acre-ft in the lower Colorado region (Pacific Southwest Interagency Committee, 1971b, p. 10). However, ground-water storage has accumulated over hundreds to thousands of years, but the surface-water storage is replenished yearly.

\section{DEGRADATION OF GROUND WATER}

In places where the ground-water aquifer hàs low capacity and is near the surface, degradation or pollution

TABLE 1.-Estimated volume of recoverable ground water in storage in the main alluvial aquifers in the lower Colorado region

[Modified from Brown (1976). Numbers rounded. See figure 1 for subregion boundaries]

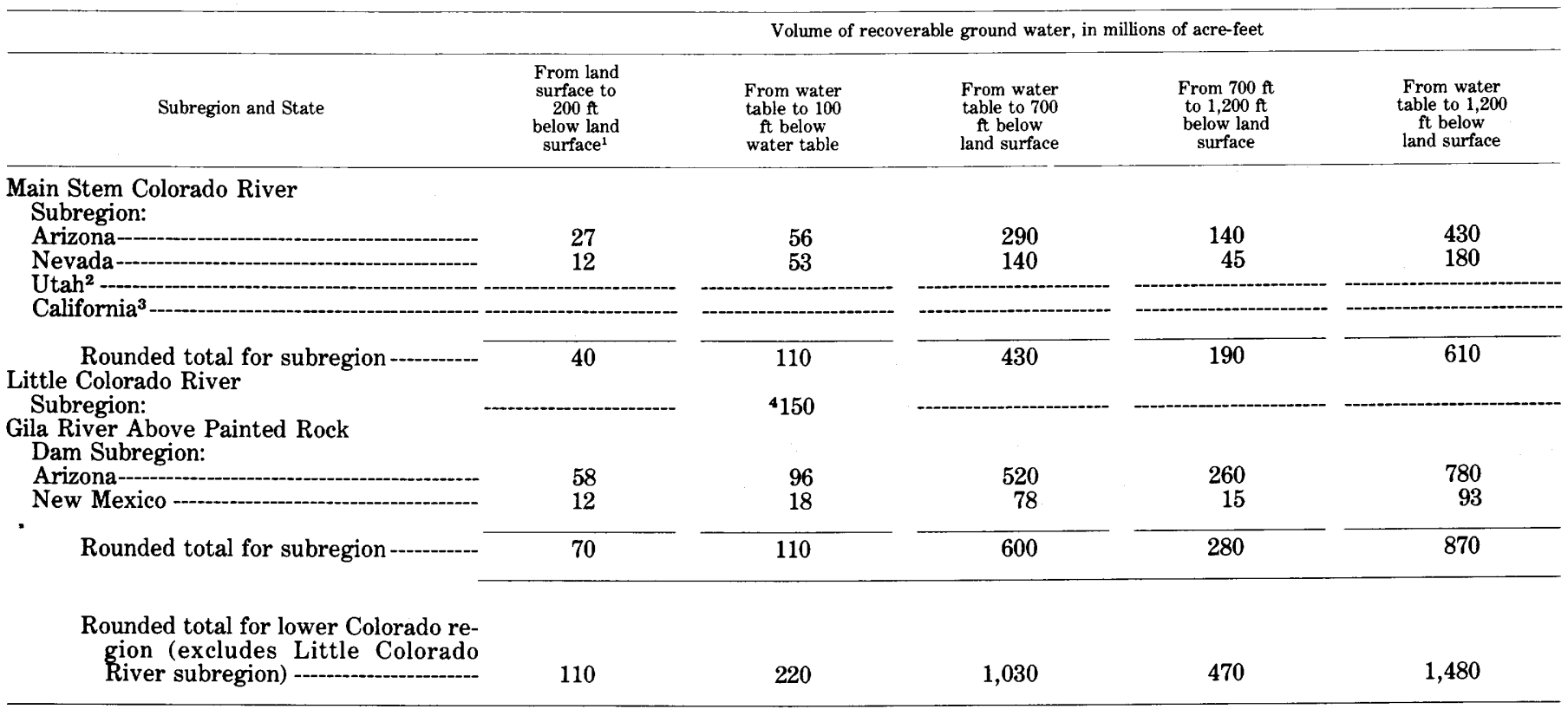

${ }^{1}$ Depth to water is 200 feet or less below the land surface in 13,600 square miles-10,900 squares miles in Arizona, 1,500 square miles in Nevada, and 1,200 square miles in New Mexico. The total square miles constitutes about 10 percent of the region.

2The quantity of ground water stored in the alluvial aquifers in Utah is minor; the quantity in consolidated rocks is not calculated.

3The quantity of ground water in the California segment is poorly known; because it is considered to be minor, it was not calculated for this study. acres is underlain by the three aquifers, and about 150 million acre-feet of ground water is stored in a typical 100-foot-thick section of aquifer. 
of the supply owing to recycling and infiltration of onceused water is potentially a serious deterrent to continued use of the supply. In such places, the degraded supply cannot easily be isolated by drilling deeper or elsewhere, or by selecting uncontaminated parts of the aquifer for a supply. The earliest use of ground water in Arizona caused serious problems in places, either because of waterlogging of the land or because of degradation of the chemical quality of the water by recycling. The degradation of chemical quality results primarily from evaporation of the applied water, subsequent concentration of salts in the residual, and then recharge of the salt-laden water to the aquifer (Harshbarger and others, 1966, p. 4-23). The problem of contamination of the salt-laden water typically has been avoided by drilling deeper wells and drawing better-quality water from deeper parts of the aquifer. Additionally, decline of water levels eliminated waterlogging and reduced the volume of salt that accumulated owing to evaporation from waterlogged land. Degradation of chemical quality of the water by use for irrigation now seems to be a minor problem in the lower Colorado region. In fact, in most of the area it is not possible to detect a major degradation of chemical quality that clearly results from return of water applied at the surface. However, in places, some of this return irrigation water is trapped temporarily in beds perched above the main aquifer, and the chemical quality of the perched return water is poorer than that of the original applied water.

Other potential water-pollution problems exist locally. In particular, sewage contains about $300 \mathrm{mg} / \mathrm{L}$ more dissolved solids and has more nitrogen and phosphorus than the original supply. The waste-disposal ponds utilized by various industries, but principally in copper-ore beneficiation, contain water much more highly mineralized than the original supply. Infiltration of this waste water to an aquifer may cause degradation of the supply, depending on the chemical quality of ground water in the area of percolation. Inadvertent dumping of liquid chemicals and unknown leakage below ground from liquid chemical and hydrocarbon storage also causes pollution of the ground-water supply. To date (1977) most of these problems have been minor and highly localized.

\section{SUMMARY OF GROUND-WATER USE}

Almost 6 million acre-ft of ground water was pumped in the lower Colorado region in 1975 (table 2). The increase in pumpage for the region over the years parallels the pumpage increase in Arizona (fig. 4). The major use of this water is for irrigated agriculture (fig. 5). Industrial uses, especially for mining and power generation, are increasing, as is municipal use because of the increase in population in some parts of the region. However, in 1975 industrial and municipal uses accounted for less than 10 percent of the total (fig. 5). Rural, domestic, and livestock supplies accounted for only a minor amount of the total ground water pumped in the region.

The largest use of ground water is in the Basin and Range lowlands, particularly in the Gila River above Painted Rock Dam subregion (fig. 1, table 2). In 1975 almost 85 percent of the total region pumpage was extracted and applied in the Gila River subregion and most of that was pumped in Arizona. Of that total subregion

TABLE 2.-Estimated ground-water pumpage by subregion and use in the lower Colorado region, 1975

[Data from U.S. Bureau of Reclamation (1975) and from the files of the U.S. Geological Survey offices in Arizona, Nevada, New Mexico, and Utah. Numbers rounded to nearest 100 acre-feet except as indicated. See figure 1 for subregion boundaries]

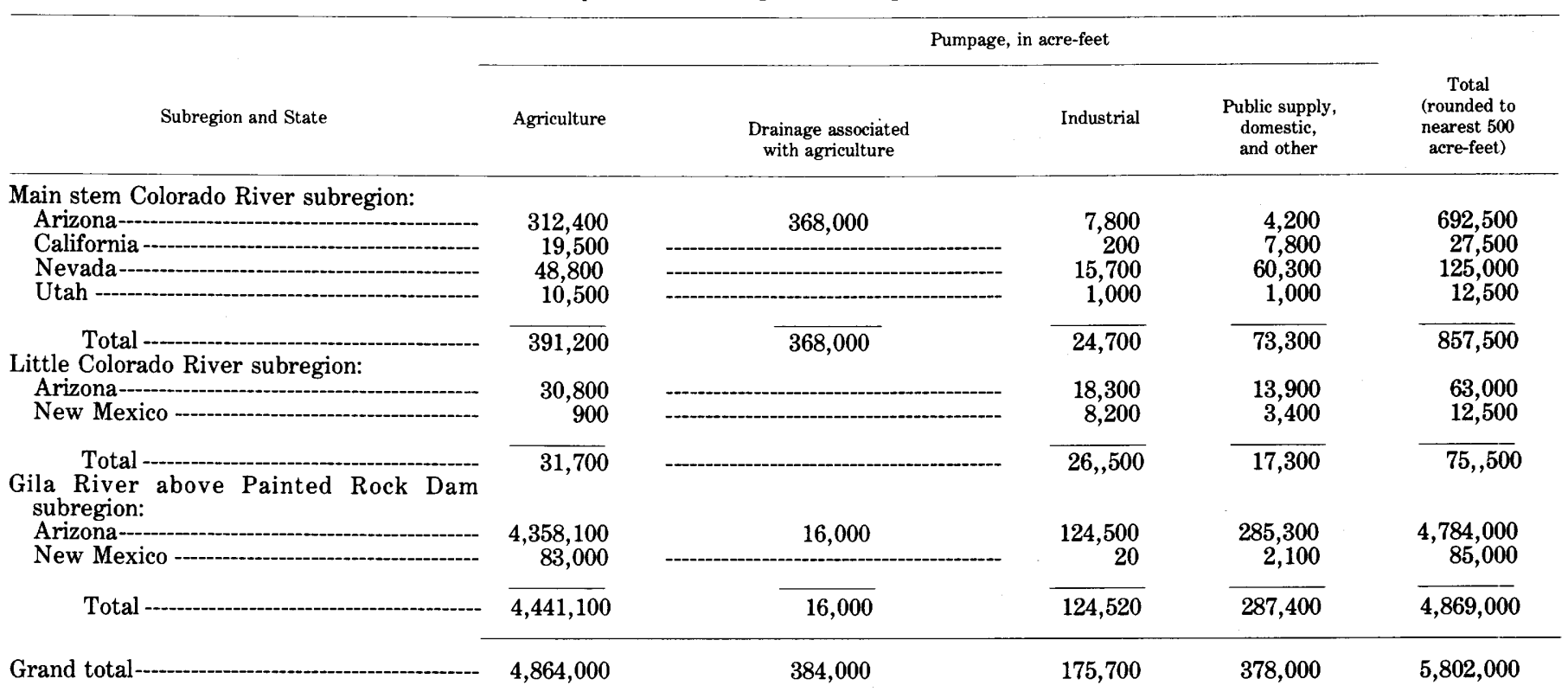




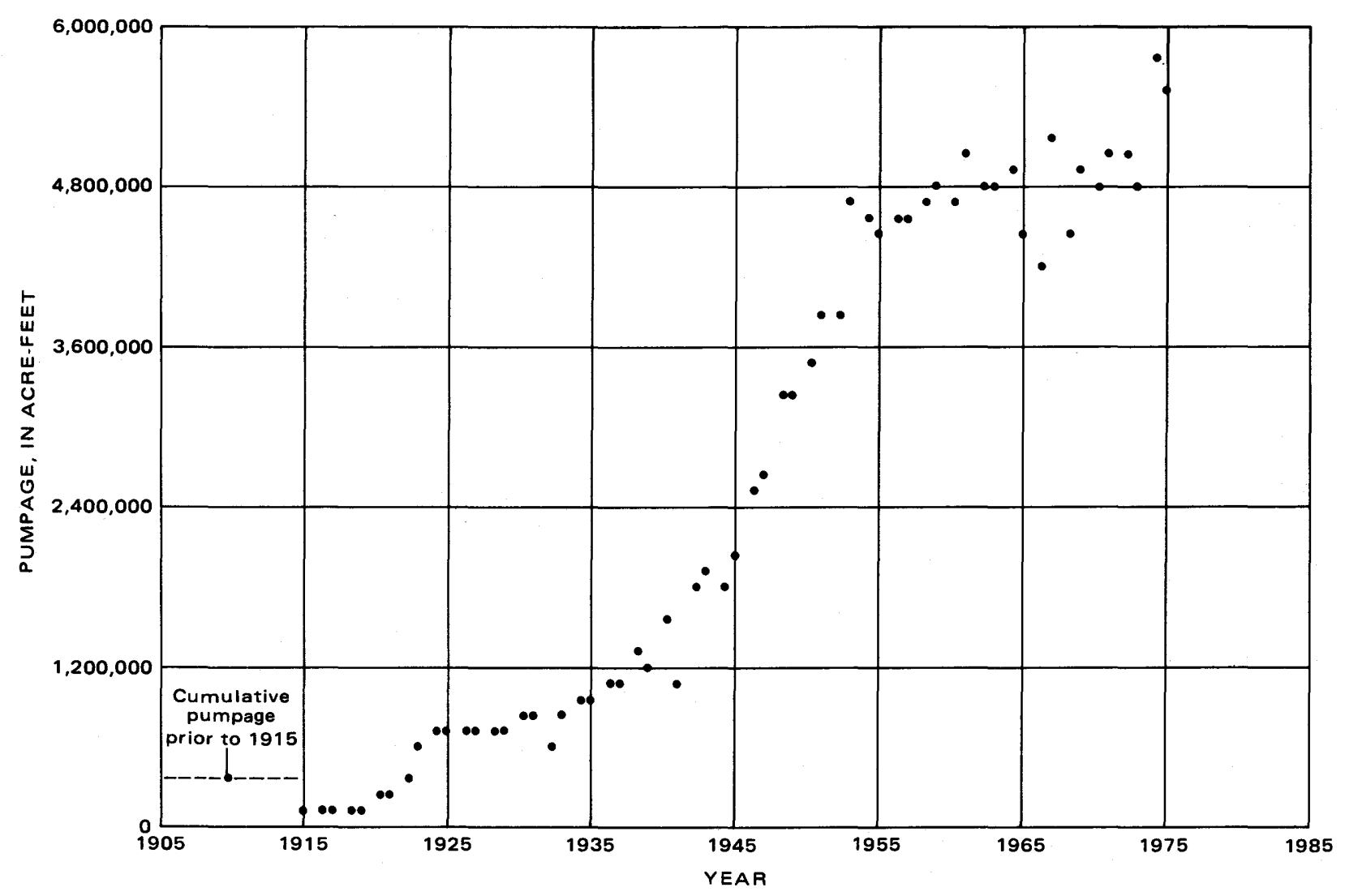

Figure 4.-Pumpage in Arizona from prior to 1915 to 1975.

pumpage of almost 4.9 million acre-ft, about 8 percent, 412,000 acre-ft, was used for industrial and municipal purposes. Some small part was pumped for drainage and for rural, domestic, livestock, and miscellaneous uses; 91 percent, 4.4 million acre-ft, was used for irrigation of crops. The next largest use is in the main stem Colorado River subregion, where almost 860,000 acre-ft was pumped in 1975. As in the Basin and Range lowlands, the major use (about 90 percent) was for irrigation, including a substantial amount of pumpage to drain waterlogged land to permit irrigated agriculture. The pumpage in the Little Colorado River subregion, which encompasses most of the Plateau uplands water province (fig. 1), was only about 75,000 acre-ft in 1975 (table 2) and agriculture accounted for about 41 percent-considerably less than in the other two subregions.

Slightly more than 175,000 acre-ft of ground water was used in 1975 for industrial use, and more than half this was used for mining. Most of the rest was used for energy production.

About 165 million tons of copper ore was mined and milled in Arizona in 1972 (U.S. Bureau of Mines, 1974, p. 75,76$)$. Slightly more than 153 million tons was concentrated and 12 million tons treated for extracting copper in heap-leach or vat-leach operations. Average use was $260 \mathrm{gal}$ of water per ton in the concentration process, including transport of tailings, and at least $125 \mathrm{gal}$ per ton in the heap- and vat-leach operations (L. C. Halpenny, written commun., 1975). This water, known as "makeup" water, is the amount of new water that must be supplied to the mining operation. Water used in the concentrating process is in a closed system, and consumptive losses are small, except for the water used to transport residual fine-grained waste rock to a "tailings pond" disposal site. According to Halpenny, about 100-260 gal of water per ton (of ore) is not recoverable from the tailings pond, owing to evaporation or retention of water in the finely ground waste rock. Water used in the leach operation is evaporated, and the loss is $125 \mathrm{gal}$ per ton or greater. The consumptive use of ground water for mining is not well known, but in 1975 it may have been in the range of 75,000-130,000 acre-ft.

Water used in energy production is becoming a more significant consumptive use every year in the lower Colorado region; evaporation of water to condense exhaust steam accounts for the greatest consumption (Davis and Wood, 1974, p. 3). The average rate of water use per unit of energy capacity is about 15 acre-ft per year per megawatt (1,000 kilowatts) for fossil-fueled plants, 22 acre$\mathrm{ft}$ per year per megawatt for nuclear-fuel plants, and 48 


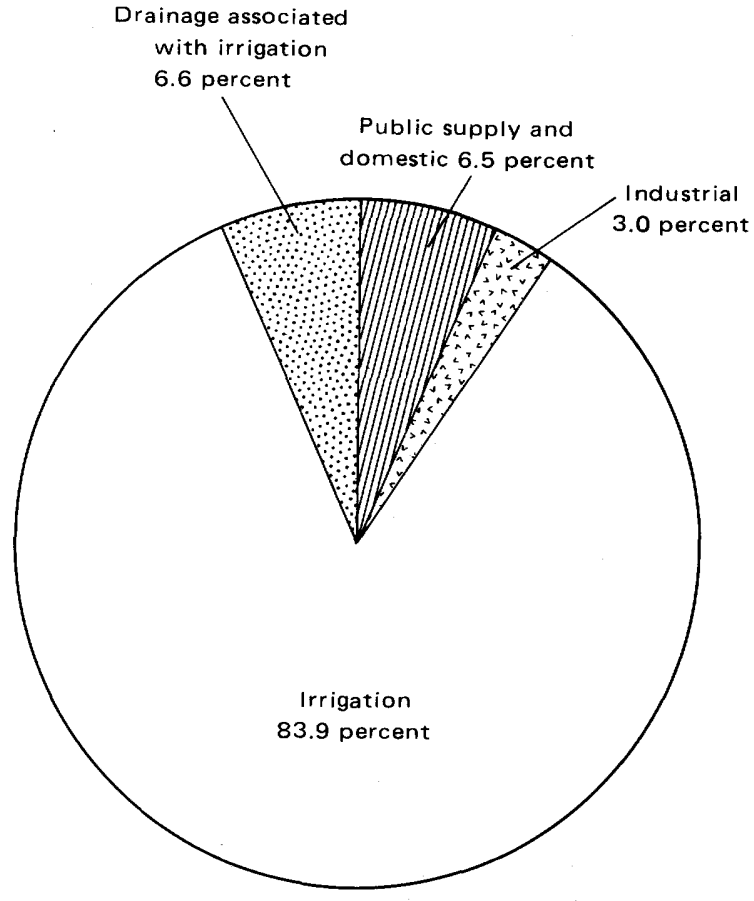

FigURE 5.-Major uses of ground water pumped in the lower Colorado region in 1975 .

acre-ft per year per megawatt for geothermal powerplants (Davis and Wood, 1974, p. 8). Water consumption in the region for electric power in 1965 was reported as 9,600 acre-ft (Pacific Southwest Interagency Committee, 1971c, p. 129), and by 1970 in Arizona alone the consumption had increased to 36,000 acre-ft (Murray and Reeves; 1972, p. 24). Ground water made up slightly more than 95 percent of the consumption. Since then, consumption of ground water has increased, and two new plants using Colorado River water have started in operation. The consumption in the region in 1975 was about 67,000 acre-ft, of which about 35,000 acre-ft, or 52 percent, was supplied from ground water.

Yearly increases in peak demands of 400 to almost 1,400 megawatts are estimated by the Electric Power Work Group of the framework study for the period 1970 to 2000 (Pacific Southwest Interagency Committee, 1971c, p. 49) compared to increases of 160-180 megawatts in the period 1955-65. Energy capacity estimates of the Economic Work Group that contributed to the same framework study are in the lowermost range (Pacific Southwest Interagency Committee, 1971a, p. 140) of peak demand predicted by the energy group. Some of the power to meet this demand will be generated outside the lower Colorado region.

The water demand anticipated by the Energy Work Group for 1980 is about 36,000 acre-ft and in the year
2000 is 106,000 acre-ft (Pacific Southwest Interagency Committee, 1971b, p. 36, 38; 1971c, p. 129). A water demand of 37,800 acre-ft in 1980-plus 7,400 acre-ft of initial supply for pumpback-power generation-was calculated by the Economics Work Group (Pacific Southwest Interagency Committee, 1971c, p. 144). However, in the year 2000, the calculation based on the economic analysis is a consumptive use of only 38,800 acre-ftplus 9,300 acre-ft for initial supply in pumpback-power generation (Pacific Southwest Interagency Committee, 1971c, p. 144) - or less than 40 percent of the amount predicted by the Energy Work Group (Pacific Southwest Interagency Committee, 1971c). Both estimates may be low; on the basis of ongoing power-generation station construction and announced plans for new construction, a consumptive use of at least 100,000-150,000 acre-ft per year should be anticipated. Estimates prepared for the Energy Research and Development Administration predict a 10-fold growth between 1975 and 2000 in water consumption for energy development (MITRE Corp., 1977, p xiv).

\section{POTENTIAL OF GROUND WATER TO SUPPORT MORE DEVELOPMENT}

The history of water development in the lower Colorado region is one of surface-water supplies being "supplemented" by water from storage in the ground-water reservoirs. The State of Arizona projected alternative levels of water development that are thought to bracket the range of possible future consumptive use in the State (Arizona Water Commission, 1977). The report concludes that "water supplies of the State would either have to be augmented, or ground-water overdraft increased substantially," or that "uses be reduced to a level that can be sustained with existing dependable supplies without resorting to appreciable ground-water overdraft" (Arizona Water Commission, 1977, p. xiii). The projections (table 3) are for consumptive use of all water estimated for 1970 and projected to 1990 and 2020. Projections for the parts of Nevada, California, Utah, and New Mexico in the region might show the same ratio of increase for urban use, mineral production, and electric

TABLE 3.-Projections of annual water depletion in Arizona

[All values in thousands of acre-feet per year. Source: Arizona Water Commission (1977,
p. $2-5,67-72)]$

\begin{tabular}{|c|c|c|c|}
\hline \multirow[b]{2}{*}{ Consumptive water use } & \multirow[b]{2}{*}{$\begin{array}{l}\text { Estimated } \\
\text { for } 1970\end{array}$} & \multicolumn{2}{|c|}{ Projected for } \\
\hline & & 1990 & 2020 \\
\hline 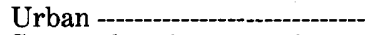 & 328 & $423-568$ & $542-950$ \\
\hline Steam-electric generation --- & 20 & $109-178$ & $248-787$ \\
\hline Mineral production -- & 131 & $236-337$ & $265-841$ \\
\hline 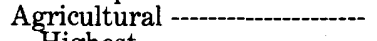 & 4,300 & & \\
\hline $\begin{array}{l}\text { Highest - } \\
\text { "Zero overdraft" - }\end{array}$ & & $\begin{array}{l}4,600 \\
3,800\end{array}$ & $\begin{array}{l}4,500 \\
2,500\end{array}$ \\
\hline
\end{tabular}


generation, probably resulting in a reduction in agricultural use. In 1975 the use of ground water was more than 1.5 times that of surface water, and the potential for further economic or large-scale ground-water development was constrained by location and availability, depth to water, poor chemical quality, and potential hazards.

Large-scale withdrawal of ground water presents some problems, particularly in the Basin and Range lowlands. Land subsidence has occurred in the Las Vegas area in Nevada and in Arizona. Earth cracks, many miles long and that range from a few inches to several feet wide, are widespread in central Arizona, mainly on the perimeter of the areas of greatest water-level decline and particularly where much of the withdrawn ground water was stored under partially confined (semiartesian) conditions (Schumann, 1974). Increased pumping of ground water in these areas will increase the problems of subsidence and earth cracks. Likewise, continued large-scale withdrawal of ground water from areas not yet affected probably will cause additional land subsidence and earth cracks. In some areas in this part of the lower Colorado region, a part of the recoverable ground water in storage contains dissolved solids substantially in excess of $1,000 \mathrm{mg} / \mathrm{L}$ (plate 1) and requires treatment to make it suitable for most uses. Some areas where large amounts of ground water are stored are remote from areas of potential use. Use of this water requires either transport of the water or very high cost of new developments in the immediate vicinity of the supply. Large amounts of water can be obtained from some of the deeper basins, but much of the untapped groundwater reserves are at depths of more than $500 \mathrm{ft}$. Use of this water is costly and would require detailed well design and spacing and the construction of much deeper wells than currently exist in most areas.

In the Plateau uplands the few alluvial aquifers do not store large amounts of ground water. However, the sandstone and limestone aquifers store very large quantities of recoverable ground water, but the potential for large-scale future use is limited by low to moderate well yields.

In the Central highlands the storage of ground water is not large per unit area except in a few basins. In these basins and in some parts of the Uplands province in eastern Arizona and western New Mexico, where volcanic rocks dominate, water supplies are large and dependable enough to support small communities and industries. The water supply in the Central highlands province probably is adequate for most foreseeable developments, largely because the terrain is not conducive to large-scale agriculture or heavy industry, except mining. The mining industry may be able to design for lower water consumption than is the current normal practice. Water use for tourism and recreational facilities is the largest use of ground and surface water in the area.

\section{EXTENSION OF THE GROUND-WATER SUPPLY}

Other than importation of surface or ground water to places of current use, more water may be made available by physically increasing the supply and by increasing efficiency of use. Schemes to increase the supply include efforts to increase precipitation and to increase recharge of surface water that might otherwise be lost directly to the atmosphere. Increases in efficiency imply conservation in use of water and reduction of natural uncontrolled evapotranspiration losses of both ground water and surface water.

\section{INCREASING THE SUPPLY}

Importation of water from regions beyond the Colorado River basin is being considered, and the Central Arizona Canal now is being constructed to carry Arizona's entitlement of Colorado River flow into the central part of the State. The U.S. Bureau of Reclamation is conducting weather modification experiments in an attempt to determine whether or not precipitation can be increased on a regional basis. Except for the mention of these major programs, a discussion of increasing the total water supply of the region by importation of surface water or by weather modification is beyond the scope of this report.

Techniques for increasing the supply of ground water involve transfer of water consumption from the present natural or virtually uncontrolled state to a use controlled by man. The total supply would not be increased, but the proportion available for man's use may be increased.

\section{INCREASING NATURAL RECHARGE}

In most of the region, ground-water withdrawal has lowered water levels. In places where ground water now evaporates at the surface, such as along the middle reaches in the Little Colorado River, ground-water lowering is a practical first step in reducing uncontrolled losses. Lowering of a water level that is near surface or that feeds a flowing stream will decrease not only the natural water loss to evapotranspiration but also the surface flow and underflow downstream. In the circumstance of original near-surface water levels, which was fairly common along streams in the region, much floodflow ran off downstream because of lack of storage space under the streambed; lowering of water levels creates storage space in the dewatered part of the aquifer, following which floodflow can recharge the aquifer. Assuming adequate space is available, the limit to the increase in recharge is relative to the total flow and to the relation 
between the rate of streamflow and the rate of infiltration to the aquifer (Burkham, 1970b). Where the original water level everywhere is deeper than about $25 \mathrm{ft}$, the probable evapotranspiration loss is small, and space is available to accept floodflow infiltration. Additional lowering of the water level will provide more storage space for recharge, but it will not alter the rate of infiltration. In an area where the water level intersects the streambed or is near surface and is tapped by plants, attempts to increase recharge without lowering water levels probably would only increase uncontrolled loss.

Schemes to increase natural recharge along streams generally require alteration of stream courses or diversion of streamflow to areas other than the channel (American Society of Civil Engineers, 1949, p. 61, 62; Laverty, 1945; Richter and Chun, 1959; Todd, 1959). Flood-control dams, coupled with controlled release, can successfully increase recharge rates (Babcock and Cushing, 1942), but many of these dams are economically justifiable only if they provide flood protection. Recharge also may be increased by diverting streamflow into secondary channels, into unlined canals, or into recharge pits. Simple disking or breaking of the crusted surface of major arroyos following floodflow would also increase the recharge from medium and low flows after the water has cleared.

Increasing streamflow infiltration in one area may only change the location of recharge and fail to increase the total amount of recharge. This condition usually prevails when the amount of streamflow is small. However, if the downstream site of recharge is an area where the water is evaporated or contaminated by mixing with poor-quality water, induced upstream recharge might be practical.

\section{ARTIFICIAL RECHARGE}

Artificial recharge is feasible mainly in areas where surface water is abundant and unused, and where there is adequate underground storage space to accommodate the recharged water. The lower Colorado region is deficient in surface flow, and nearly every drop of available surface water is utilized or appropriated. The legal status and ownership of surface water is clear, but the status of recharged ground water is not in many places. This problem may be a major impediment to artificial recharge in Arizona, where surface and ground water have differing legal status.

Artificial recharge is practiced on a small scale in Phoenix, Ariz., where water is pumped out for cooling purposes and returned through recharge wells. Another method of recharging water to underground storage is the diversion of temporarily surplus water in a reservoir to streambeds where the recharge mechanism operates under natural conditions. Water recharged in this man- ner may be recovered by wells. The Salt River dam and reservoir system in the Phoenix area so operates when release of water is necessary to provide additional storage for control of predicted flood runoff. Almost all the water released during one period was recharged to the aquifer in the Phoenix area (Briggs and Werho, 1966).

Although artificial recharge is a management tool for increasing the amount of water in storage and for decreasing the loss of water stored on the surface, currently very little water is surplus or available to be recharged. Artificial recharge may be used effectively to change the location of current natural recharge.

\section{WATERSHED MANAGEMENT-INCREASING RUNOFF AND DECREASING EVAPOTRANSPIRATION}

In the lower Colorado region, more than 95 percent of the precipitation is lost through evaporation and transpiration. If the amount of water lost to the atmosphere could be reduced even by a small percentage, the amount of usable surface water and ground water would be markedly increased. Since publication of the Barr reports in 1956 (Barr, 1956a, 1956b), a great deal of effort has been put into research and pilot programs in Arizona to assess the potential for increasing water yield by vegetation management on watersheds.

Small-scale experiments in mixed conifer and ponderosa pine forests, pinyon-juniper woodlands, and chaparral vegetation zones indicate that removal and (or) replacement of the original vegetation will increase the water yield. Operational and experimental programs in control or removal of riparian plants also result in an increase in water yield. However, results of the wateryield experiments cannot be extended to larger areas with certainty, and it is not known that the increased water yield will survive transmission losses prior to flowing into a surface reservoir or recharging a usable ground-water aquifer. The cost of management maintenance makes the additional runoff costly, and replacement of cleared woody vegetation by grass or forbs reduces the original increase in runoff.

Ffolliott and Thorud (1974, p. 34-36) concluded that water yield could be increased in mixed conifer, ponderosa pine forest, chaparral, and riparian vegetation zones, and they recommended increased data collection and research to evaluate the experimental results. Their analysis of existing data indicated that in Arizona about 0.5-1.2 million acre-ft of potential increased water yield could result from treatment of 6 million acres of mixed conifer, ponderosa pine forest, and chaparral vegetation. They estimated a potential yield of 2 acre-ft per acre for management of 300,000 acres of riparian vegetation for a total annual potential of another 600,000 acre-ft (Ffolliott and Thorud, 1974, p. 22). 
The use of watershed management solely to increase ground water in most of the region does not seem promising, owing to land treatment and maintenance costs and the distance between the additional runoff and the ground-water storage area. Additional water might be derived through range and forest management practices designed to increase runoff, but the program costs seem to require surface storage or nearby use of this water rather than increased ground-water recharge.

\section{INCREASING THE EFFICIENCY IN USE OF WATER}

The greatest potential and the most economical method of extending the ground-water and total water supply probably is to increase the efficiency of water use. In general, efficiencies should reduce the inadvertent or uncontrolled loss of water to the atmosphere or to places where it cannot be recovered for years or even decades. Multiple reuse of water is practiced generally in the region. In many cases, the reuse is accidental or inadvertent, but the mining industry and utilities in particular make an effort to reuse water. At this time, most conscious reuse is dependent on economics rather than simple conservation; however, water becomes more expensive each year, and more and more large users are instituting water-recycling systems. The extent and management of recycling are carefully planned because water becomes more highly charged with dissolved solids following each cycle. Eventually, particularly in cooling uses, recycled water has so high a concentration of salts that it must be removed from the system.

Conservation can prevent or delay some of the problems associated with ground-water exploitation. Planned reuse of sewage and water used for cooling and slurry transport and innovative design that reduces or eliminates large-scale use of water are necessary to conserve the supply. Efficiency of irrigation can be improved markedly through canal lining and different methods of application, such as sprinkling and drip irrigation methods. In some areas in the region irrigated lands have been forced out of production by urbanization or by municipal purchase; their associated ground-water supply is used to meet less water-demanding urban needs.

The capital cost of instituting conservation practices must be met now largely by individual entities because of current legal impediments and lack of areawide management options. The threat to economic, industrial, and population growth caused by lack of conservation is only dimly perceived, and the threat is not deemed as immediate a problem as capital expenditures. An attempt in 1976 by the City Council of Tucson, Ariz., to institute conservation practices through a pricing mechanism resulted in a recall referendum and a replacement of the council majority.

\section{CROP IRRIGATION}

The greatest demand on water in the region is for irrigated agriculture; irrigation accounted for about 90 percent of ground water (fig. 5) and total use in 1975. In Arizona about 7 million acre-ft of water was applied on about 1.2 million acres of cropland in 1970 (Arizona Crop and Livestock Reporting Service, 1974, p. 1) for an average annual use of almost 6 acre-ft per acre of harvested crop. In 1973, 1.4 million acres of crops was grown using about 7 million acre-ft of water for an average of about $5^{1 / 2}$ acre-ft per acre of crop. The actual applications of water for irrigation probably ranged from about $2^{1 / 2}$ acre$\mathrm{ft}$ per acre for some pasture and hay crops to about 40 acre-ft per acre for citrus crops grown on very permeable ground in the Yuma area. The consumptive use of water by most crops grown in the region ranges from about $1 \frac{1}{2}$ acre-ft to about 6 acre-ft of water per acre (Erie and others, 1965). The soil water required for growth of most forage, fiber, fruit, and oil crops in 40-50 in. per year or growing season and for most grain and vegetable crops is 16-25 in. per growing season (Erie and others, 1965). However, considerable additional irrigation water per acre is evaporated because of water applications necessary to encourage germination, control pests, protect from frost, and for cooling to improve quality or preserve crispness (lettuce). (See Erie and others, 1965, p. 6). In the area of greatest agricultural development, the annual potential evapotranspiration ranges from 35 to $50 \mathrm{in}$. per year (Buol, 1964).

Methods of accurately measuring the total water consumed in crop growth require a complete accounting of water applied; such an accounting is much too cumbersome, expensive, and time consuming to be applied generally. Therefore, total consumption has been estimated by use of equations derived from prior research where a budget-accounting process was used for control. Methods suggested by Thornthwaite (1948), Blaney and Morin (1942), and Blaney and Criddle $(1950,1962)$ use empirical formulas to calculate evapotranspiration. These formulas are in common use primarily because climatic data necessary in the calculations are available. A more accurate and physically valid method was presented by Penman (1948, 1956a, 1956b), but the necessary data for solution are not commonly available in existing meteorological records, not are they easily obtained. The value of the Thornthwaite and Blaney-Criddle methods in determining total consumption of water is dependent on prudent irrigation. If fields or parts of fields are "overwatered" in respect to plant growth needs, then the estimates of consumption are likely to be low.

Efficiency of water delivery and application is becoming a more significant part of agricultural expense, and more and more effort and capital investment is being put 
into improving the efficiency of applying water to crops. If water costs are not great, the irrigation systems are rather crude and are subject to large conveyance losses and inefficiencies in water application; the greatest losses are by seepage from ditches and wastage by evaporation of excess applied water and of tailwater that accumulates in the lower ends of the irrigated fields. In the last 20 years, owing largely to the cost of delivering water and secondarily to the shortage of water, more and more irrigators have installed sealed transmission ditches and systems for pumping back "tailwater" from the ends of the fields. However, change is slow, owing to the relatively low value of the product and the high initial cost of a new irrigation system to replace one already in existence.

The ideal arrangement for water conservation is application of just enough water to meet the growth needs of the plant and enough excess to flush downward the salts that accumulate in the soil because of transpiration of water by the plants and evaporation. The ideal system would eliminate unnecessary evaporation and seepage. Most crops are irrigated by flooding the entire field or by running water in furrows, but in parts of Arizona where water cost is a factor, sprinkler systems and drip irrigation are replacing the flood method. In the Yuma area, as reported by Lucas (1975), flood irrigation of citrus trees required 11 acre-ft per acre per year, but a change to drip irrigation dramatically lowered the demand to 6 acre-ft; saving of water also was achieved by changing from flood to sprinkler irrigation of grain crops (Lucas, 1975, p. 24-25). Further, according to results reported by Lucas (1975), the capital investment and maintenance cost of drip or sprinkler irrigation is less than that of flood irrigation.

The operational benefits in 1974-75 justified costs of shifting to a drip irrigation system in Yuma; there, installation of a flood irrigation system was about $\$ 520$ per acre, whereas installation of more efficient drip irrigation in the same area was about $\$ 400$ an acre, or $\$ 120$ per acre less. Similar savings were reported using sprinkler irrigation instead of flood irrigation. In most places in the region where large quantities of water are used, the $1970-75$ cost of water was in the range of $\$ 3$ to $\$ 15$ per acre-ft. However, the project to deliver 1.2 million acre$\mathrm{ft}$ of Colorado River water to central Arizona will cost $\$ 2.1$ billion for construction, and operation and maintenance costs are estimated at about $\$ 100$ per acre-ft (Lucas, 1975; City of Tucson, 1974, p. 54-61, 83-97). Because of the low costs now current in most places, an economic incentive for improvement of irrigation efficiency by installing a new irrigation system on presently irrigated lands will have to rely on reduction of costs other than that of water.
An alternative crop growth and economic incentive to reduce water consumption was suggested by Kelso, Martin, and Mack (1973) reporting on an 8-year study financed by the Rockefeller Foundation and the University of Arizona. They (Kelso and others, 1973, p. 26, 27) indicated that

scarce water supplies are, by legal devices and by reasons of location, locked into uses in which the marginal value of the product of the water is extremely low-approaching zero in some cases. $* * *$ curtailing water uses producing lowest net income $* * *$ expanding $* * *$ higher $* * *$ net income per unit of water, can release growth of the Arizona economy from all restraint by water, well into the twenty-first century.

A later report (Kelso and others, 1974) and several public addresses by the authors and their colleagues (oral commun., 1973-76) indicated that it is more economical to import many high-water-consumption crops, such as alfalfa and forage, than to produce them in Arizona. Some of the water used to grow these animal feed stocks could be converted to higher value uses, but, more importantly, total water use could be drastically reduced with no measurable negative impact on the economy of the lower Colorado region.

\section{PUBLIC SUPPLIES}

Consumptive use of water in public supply can be reduced substantially. Consumptive-use calculations trace most of the consumption to outside watering of lawns and plants rather than to inside-home use. Home, city, town, and subdivision designs that reduce the desire or need for abundant outside growth or that substitute lowwater-need desert growth can halve the current 180-200 gal per day per capita use and 90-100 gal per day per capita consumption. However, the use of water for public supply is only 6.5 percent of the total ground-water use (fig. 5) and only about 5 percent of all the water used (1975) in the region.

\section{SEWAGE EFFLUENT}

Sewage effluent is discharged onto permeable areas where it infiltrates to ground water or is reused for irrigation or industrial purposes. In some places the effluent is discharged into a flowing stream or a body of water; for instance, some of the treated effluent from the Las Vegas area is discharged via Las Vegas Wash into Lake Mead. The dissolved-solids concentration of the effluent may be less than that of the native ground water in the area of discharge. This condition holds for the Phoenix, Tucson, and Las Vegas areas. In other places, particularly the smaller cities and towns, the reverse is true. The principal disadvantage of recharged sewage effluent is its concentrations of boron, nitrate, and phosphate. Sufficient concentrations of boron are injurious to growing plants, nitrate concentrations greater than 10 
$\mathrm{mg} / \mathrm{L}$ are a health threat to infants (National Academy of Sciences and National Academy of Engineering, 1973, p. 73), and nitrate and phosphate compounds encourage unwanted vegetal growth where effluent wets surface soil or enters surface-water bodies.

In most parts of the region sewage effluent is considered a cheaply available source of water, and considerable effort has gone into reusing the resource. The Tucson metropolitan area now uses effluent to water a park and hopes to use a major part for industrial uses and possibly for irrigation of crops. Effluent from the Phoenix metropolitan area is used for irrigation, and effluent from Las Vegas is used for irrigation of crops and a minor amount in power generation. Effluent from most other communities in the region is not consciously reused and is either discharged to flowing streams, recharged to ground water, or evaporated.

The trend in the region seems to be toward greater use of sewage effluent in industrial processes, such as copper-ore beneficiation, power generation, and cooling. Much effluent is used to irrigate forage crops, but owing to cost and conservation factors that might give higher priority to public supply and industrial use, irrigation usage seems likely to diminish.

\section{INDUSTRIAL USES}

Most.industrial water-use systems are designed to make the maximum use of water prior to its loss by evaporation and, in general, the amount of evaporation is a necessary and integral part of the industrial process. The greatest uses are for mining and milling of copper ore and for generation of electric power.

As noted in the section on "Summary of Ground-Water Use," an average of $260 \mathrm{gal}$ of water per ton of ore is used in the ore-concentration process, and half to all this water is not recovered in most operations. The dominant loss of this water is associated with hydraulic transport of finely ground waste rock to tailings ponds. Prior to 1975 , many waste-rock tailings ponds were so constructed that seepage through the bottom of the pond was a substantial part of water loss from the system. Many new tailings ponds now are effectively sealed by first coating the raw earth surface with fine slimes produced in the milling operation. This procedure might reduce the rate of water consumption per ton to $100-125$ gal or less.

Water used in most steam-electric generation stations in the lower Colorado region is recycled, and nearly all new plants utilize water to complete consumption. Water consumption in thermal and geothermal powerplants probably cannot be lowered owing to present high efficiencies or operating constraints. Consumption of water in nuclear power-generation plants is considerably greater than that in thermal plants, and the consumption can be reduced (Davis and Wood, 1974, p. 8); however, no nuclear plants were operating in the region as of 1978 and the first plant, near Phoenix, is scheduled to start in 1982.

\section{POTENTIAL USE OF SALINE WATER}

Saline water generally is not used in the lower Colorado region. Large quantities of saline ground water occur, and as much as 50,000-70,000 acre-ft per year may be lost to evaporation or to uncontrolled transpiration by plants. However, the cost of treatment to allow use of saline water is so high as to be prohibitive if other water sources are available.

In northern Arizona, considerable water is lost to evapotranspiration along the Little Colorado River (fig. 1). There, saline water underlies freshwater, and a mixture of both is near surface and adds to the river flow. Withdrawal of the fresh groundwater for projected expansion of a thermal powerplant in the area will reduce the head in the entire aquifer, and with time the flow of both freshwater and saline water to the surface will diminish. It is not now economic to use saline water in powerplants, but in this case, usage of freshwater will reduce loss of both freshwater and saline water.

In other parts of the region, large quantities of saline ground water are available, and as freshwater becomes more and more expensive to pump or transport, these saline-water bodies will be developed. Depending on the location and the quantity withdrawn, the quantities in storage (table 1) will assure a 30- to 100-year supply or perhaps longer. Large reserves of saline ground water are present along the Little Colorado, Gila, and the Salt Rivers in Arizona, and small to moderate amounts are present along other smaller rivers in the region (Feth and others, 1965). The opportunity to produce large permanent supplies is poor, but the prospect for some shortterm developments, roughly 30-year, is good. Additionally, use of saline water will keep such water from migrating into and contaminating adjacent bodies of freshwater. This use is particularly indicated where the ground-water flow is from the area of saline water toward the area of freshwater, and the flow rate is increased with time because of removal of freshwater.

In some areas near cities in Arizona, ground water contains concentrations of nitrate, fluoride, and chromium in excess of the recommended or mandatory drinking-water standards of the National Academy of Sciences and National Academy of Engineering (1973). Some of this water is too highly mineralized to be used directly, but it could be mixed with better-quality water and used for public supply. 


\section{CONCEPTS OF GROUND-WATER USE}

\section{MINING}

Ground water is used in the region mainly according to water need and the economic formula of return versus cost. In much of the region where water levels were near the land surface at the turn of the century or later, it has been profitable and necessary to pump the amount of water needed to sustain the surface operation. Because most ground-water reservoirs in the lower Colorado region store vast amounts of water and receive relatively small amounts of recharge, the region generally has pumped and consumed more ground water than is replenished. The result of this imbalance is steady depletion of stored ground water, as reflected by water levels that decline about 2-10 ft each year throughout much of the developed part of the region. The depletion is termed "mining" because of its near parallelism with mining and permanent depletion of ore bodies. Actually, unlike an ore body, a ground-water aquifer theoretically can be returned nearly to its original saturated condition through artificially increased recharge or through reduction of use; however, time, expense, and other problems may prove artificial or induced recharge impractical in many circumstances.

In recent years much thought has been given by legislators, scientists, and water managers in the region to reconciling economic gain, conservation interests, and guarantees of water supplies necessary for all major uses. Rationally, one might expect that public supplies would be guaranteed to last forever, either by restriction of uses other than public supply, by importation, or by restriction on public-supply use. For example, in places where public supplies of ground water are threatened, it might be financially and politically possible to limit ground-water consumption to the sum of recharge plus a small fraction of ground-water storage. However, in areas where public supplies are not a critical part of the usage, an alternative plan similar to New Mexico law (Chalmers, 1974, p. 73-85) could regulate usage so as to guarantee that the life of the water supply would support an economic return on the surface development. The above concepts imply that (1) "mining" or development of stored ground water is a practical process and the resource should be developed as a mineral propertymined and planned for depletion over a known period of years, and (2) public-supply consurıption in towns and municipalities should be balanced to the renewable and assured water inflow. This last condition is not easily attained because most people equate growth with prosperity and believe that a chronic water shortage can be remedied by importation of water. Yet some towns, principally in Arizona, have been severely limited in growth owing to the lack of water and the high cost of water importation.

\section{LEGAL CONSTRAINTS}

The scope of this report allows only a discussion of the major legal constraints on ground-water use in the region. Arizona's ground-water law is close to English rule, or as stated by Chalmers $(1974$, p. 5):

The English or common law rule is a doctrine based on the theory of absolute ownership, whereby water beneath the land is considered to be strictly a part of the land in which the water is located and therefore belonging to that particular land's owner. So long as no indication of malice exists, such a property owner can utilize any amount of water from his land without liability for harm to neighboring property owners. The English rule was based on conditions in England, and on deductions from absolute private rights in land, supported by the theory that a landowner owns everything above and below his land $* * *$.

Chalmers (1974, p. 51) further stated: "As of 1973, the Arizona Groundwater Code's structure encourages landowners in areas of serious depletion to pump at the maximum rate economically feasible so as to 'get theirs' before their neighbors do."

Nevada administers ground water conjunctively with its surface water under an appropriation scheme (Chalmers, 1974, p. 72), and "as a general policy, the Nevada Code has restricted ground-water withdrawals to the average annual replenishment or 'safe yield' " (Chalmers, 1974, p. 71).

New Mexico's ground-water code provides: "The waters of underground streams, channels, artesian basins, reservoirs or lakes, having reasonably ascertainable boundaries, are hereby declared to be public waters and to belong to the public and to be subject to appropriation for beneficial use" (Chalmers, 1974, p. 74). The State Engineer now has authority to regulate use to protect prior appropriators and yet make full beneficial and economic use of the resource (Chalmers, 1974, p. 73-85).

Utah manages ground water through a prior appropriation doctrine and is able to restrict use. According to Chalmers (1974, p. 104):

The Utah groundwater law, $* * *$ has followed a chronological path, from the English rule to the correlative rights doctrine to the present prior appropriation doctrine. The present doctrinal basis permitted the elimination of the historical distinction between groundwaters, with the result that waters of all sources are declared to be public property. Since all prospective appropriators must apply for a permit, the State Engineer in his process of review is in an excellent position to administer the use of groundwater resources. Similarly, conflicting claims may also lead to a determination of the adequacy of such supplies, and to a priority-based reapportionment, and to either a restricted or full closure status for such an area. Adequate statutory flexibility, providing for accumulation of needed data and possible appointment of commissioners, exists within the code, as well as enforcement provisions.

The Utah approach appears to be a reasonably effective effort at managing that state's groundwater resources in an equitable manner that respects public and private interests. The fact that this approach 
was implemented nearly four decades ago, and that there was not then in existence situations of extensive mining of aquifers, has undoubtedly made administration of the code less painful than would be implementation at this date.

In summary, of all the States in the region, Arizona is the only State that cannot easily control ground-water use-even ground-water depletion that may do economic damage to a prior appropriator-and cannot easily resolve problems where pumping may deplete surface flow. Kelso, Martin, and Mack (1973, p. 27) commented that

*** the Arizona problem is more a problem of the lack of manmade institutions (policies) for developing and transferring water than a problem of physically short supplies. At least, the problem can be resolved more cheaply for many years to come if it is approached through institutional (policy) reform relating to water transfer rather than through development and/or importation of additional water supplies.

\section{USE OF UNDERGROUND STORAGE SPACE}

In recent years, underground space has been used for storage of resource materials or hazardous wastes. The most common use of underground space has been temporary storage of resource materials, such as natural gas and other hydrocarbons or freshwater; these liquids and gases are stored during periods of surplus and withdrawn during periods of deficiency. Underground space also is used for disposal of liquid waste, comprising caustic, toxic, or radioactive fluids. Generally, the quantities of wastes are small and do not require as much space as the resource materials.

The lower Colorado region has been explored along present routes of natural gas pipelines for geologic environments that might be favorable for storage of natural gas. The requirements for preventing uncontrolled escape of stored gas from the host rock are rigorous, and only a few areas in the Basin and Range province show promise. The El Paso Gas Co. is involved in a joint saltremoval and gas-storage scheme near Phoenix, Ariz., where salt is dissolved from a thick deposit by cycling water, using injection and recovery wells. Salt then is recovered on the surface in sealed evaporation ponds. The space created in the the deposit by salt solution and removal is used for "leak-proof" pressurized storage of natural gas. Another scheme to create natural gas storage space has been proposed for the Kingman area in Arizona. There, it is proposed to create a large cavity in large salt body by an atomic explosion. Other salt or gypsum-anhydrite deposits occur in the basins of the Basin and Range province and presumably also could be used for storage of certain fluids or gasses.

The Plateau uplands province of the region presents more geologic target areas for storage of natural gas and hydrocarbons, but the exploration and development of storage capability may be more costly than that developed to date in the Basin and Range province.

Excess water can be stored beneath the surface in much or nearly all of the lower Colorado region, but technically, the Basin and Range province contains the most practical sites. There, water can be recharged along stream courses; the recharge rate is high and efficient, and with proper planning most of the water can be recovered with very little deterioration of chemical quality. The same scheme can be used in the Colorado Plateaus area, but the location must be carefully chosen so as to yield maximum infiltration rates and yet allow complete and practical rates of recovery of the stored water. Additionally, more care is needed in this province to avoid contamination by native saline water.

The current dominant waste storage is near-surface landfill disposal of solid waste from urban areas. Storage of hazardous or environmentally objectionable materials-such as radioactive waste products, brines, and various industrial materials-has not yet occurred to any great extent in the region.

Disposal of solid urban-derived waste products should not be a major threat to public health or to ground water, but two factors in the region interfere with wise disposal. First, most of this waste is stored in existing large holes in the earth, and in this region these holes typically are "borrow pits" where gravel and sand were removed. Nearly all the gravel and sand pits are along stream courses, and, therefore, most solid waste disposal areas are subject to exhumation when the stream course changes slightly. Such changes are extremely common, particularly in the flood plains along which the landfills are located. Second, because most of the region is semiarid and humidity in the earth is low, the solid waste materials does not disintegrate or revert to soil. Newspapers buried in the last century have been recovered in good condition despite long interment. One solution is to locate solid waste sites in areas removed from major stream courses-in pits developed for the purpose of disposal or following extraction of brick clay. The danger of exhumation in such areas is minimal. Another solution is recycling of the waste into usable products or energy.

Disposal of radioactive wastes may be feasible in thick unsaturated materials between the land surface and water-saturated beds. The feasibility, criteria, and problems are discussed by Winograd (1974, p. 884-894), winu suggested the remote Nevada Test Site of southern Nevada for radioactive-waste storage. Other less hazardous materials produced in amounts that are not so large as to be unmanageable might be stored in similar geologic sites in the region.

Other environmentally objectionable fluids, such as brines from desalinization operations or from electric 
powerplants, probably can be safely and effectively injected into aquifers that contain water too salty to be utilized. Some industrial wastes also could be stored in these aquifers, but the hazard to health from uncontrolled leakage of these materials would have to be carefully assessed. Currently, most of these fluids are evaporated in place, and the solid waste is allowed to accumulate in the evaporation ponds. In some places the less toxic effluents are discharged into municipal sewagetreatment plants.

\section{SUMMARY}

Ground water has been developed extensively in the lower Colorado region and large quantities still are available for use. At the present time, particularly in Arizona, most management and planning for ground-water use has not considered whether or not ground-water withdrawal should be limited to the average annual replenishment or whether it should be pumped out to total depletion and the consequences planned for and accepted. In Arizona, the largest part of the lower Colorado region, withdrawal generally occurs to meet a need, and only total depletion or excessive cost has a bearing on ground-water management. Regionally, mixed Federal, State, and private land ownership and legal conflicts or statutes also place constraints on ground-water management. These factors frequently have proved to be significant in ground-water development and management.

In the Arizona and Las Vegas, Nev., parts of the Basin and Range lowlands province, more ground water is pumped out annually than is replenished by recharge. This condition is causing ground-water-level declines, increased pumping costs, land subsidence, and earth cracks. However, even in this highly developed province, there are places where large volumes of ground water are stored. The water in these places generally is at greater depth and may be more saline than the water in the more highly pumped areas. This potential water supply may be developed eventually. Each State in the region is considering the development of ground water in its State water plan.

The northeastern part of the region, comprising the Central highlands and Plateau uplands provinces, also contains large quantities of ground water, and, on a regional basis, the annual ground-water use does not exceed replenishment. However, areas of intensive use, such as the Flagstaff and Williams areas in Arizona, do have inadequate supplies, particularly during the summer. More ground water can be developed in this part of the region, but it will be more costly per unit of water than most ground water now pumped in the southwestern part of the area.
States in the lower Colorado region are completing State water plans that assess the water supply and accompanying problems of development, that predict possible future needs, and that provide for several future water-management options. Adequate, continuing, and up-to-date technical information about ground-water resources in the region will be necessary to select from management options that increase in complexity with time. As the water supplies become more scarce and more valuable, good management can help prevent some of the conflict that will be inevitable over the use of the water.

\section{SELECTED REFERENCES}

American Society of Civil Engineers, 1949, Hydrology handbook: Am. Soc. Civil Engineers, Manual of Engineering Practice, no. 28, $184 \mathrm{p}$.

Arizona Crop and Livestock Reporting Service, 1974, Cropland atlas of Arizona: Phoenix, Arizona Crop and Livestock Reporting Service duplicated report, $68 \mathrm{p}$.

Arizona Water Commission, 1975, Inventory of resource and usesphase 1, Arizona State water plan: Arizona Water Comm. report, $224 \mathrm{p}$.

- 1977, Inventory of resource and uses-phase 2, Alternative futures: Arizona Water Comm. report, 145 p.

Arizona Westwide Study Team, 1973, Western United States water plan, State of Arizona: Boulder City, Nev., U.S. Bur. Reclamation, $218 \mathrm{p}$.

Babcock, H. M., 1976, Annual summary of ground-water conditions in Arizona, spring 1974 to spring 1975: U.S. Geol. Survey WaterResources Inv. 76-59, 2 sheets.

Babcock, H. M., and Cushing, E. M., 1942, Recharge to ground water from floods in a typical desert wash, Pinal County, Arizona: Am. Geo phys. Union Trans., 23d Ann. Mtg., pt. 1, p. 49-56.

Barr, G. W., ed., 1956a, Recovering rainfall, Part I: Arizona Univ., Dept. Agr. Economics report, $33 \mathrm{p}$.

1956b, Recovering rainfall, Part II: Arizona Univ., Dept. Agr. Economics report, $218 \mathrm{p}$.

Blaney, H. F., and Criddle, W. D., 1950, Determining water requirements in irrigated areas from climatological and irrigation data: U.S. Soil Conserv. Service SCS-TP-96, $48 \mathrm{p}$.

1962, Determining consumptive use and irrigation water requirements: U.S. Dept. Argriculture Tech. Bull. 1275, 59 p.

Blaney, H.F., and Morin, K. V., 1942, Evaporation and consumptive use of water: empirical formulas: Am. Geophy. Union Trans., v. 23, p. $76-82$.

Briggs, P. C., and Werho, L. L., 1966, Infiltration and recharge from the flow of April 1965 in the Salt River near Phoenix, Arizona: Arizona State Land Dept. Water-Resources Rept. 29, 12 p.

Brown, S. G., 1976, Preliminary maps showing ground-water resources in the lower Colorado River region, Arizona, Nevada, New Mexico, and Utah: U.S. Geol. Survey Hydrol. Inv. Atlas HA-542, 3 sheets.

Bull, W. B., and Poland, J. F., 1975, Land subsidence due to groundwater withdrawal in the Los Banos-Kettleman City area, California, Part 3. Interrelations of water-level change, change in aquifer-system thickness, and subsidence: U.S. Geol. Survey Prof. Paper 437-G, 62 p. 
Buol, S. W., 1964, Calculated actual and potential evapotranspiration in Arizona: Arizona Univ., Agr. Expt. Sta. Tech. Bull. 162, 48 p.

Burkham, D. E., 1970a, A method for relating infiltration rates to streamflow rates in perched streams, in Geological Survey research 1970: U.S. Geol. Survey Prof. Paper 700-D, p. D266-D271.

1970b, Depletion of streamflow by infiltration in the main channels of the Tucson basin, southeastern Arizona: U.S. Geol. Survey Water-Supply Paper 1939-B, $36 \mathrm{p}$.

Chalmers, J. R., 1974, Southwestern groundwater law-A textual and bibliographic interpretation: Arizona Univ., Arid Lands Resource Inf. Paper 4, $229 \mathrm{p}$.

City of Tucson, 1974, The Central Arizona Project-A staff report to the Metropolitan Utilities Management Agency Board and the Mayor and Council of the city of Tucson: City of Tucson duplicated report, $133 \mathrm{p}$.

Cooley, M. E., and Davidson, E. S., 1963, The Mogollon Highlandstheir influence on Mesozoic and Cenozoic erosion and sedimentation: Arizona Geol. Soc. Digest, v. 6, p. 7-35.

Davis, G. H., and Wood, L. A., 1974, Water demands for expanding energy development: U.S. Geol. Survey Circ. 703, 14 p.

Erie, L. J., French, O. F., and Harris, Karl, 1965, Consumptive use of water by crops in Arizona: Arizona Univ., Agr. Expt. Sta. Tech. Bull. 169, 41 p.

Feth, J. H., and others, 1965, Preliminary map of the conterminous United States showing depth to and quality of shallowest ground water containing more than 1,000 parts per million dissolved solids: U.S. Geol. Survey Hydrol. Inv. Atlas HA-199, 2 sheets, text.

Ffolliott, P. F., and Thorud, D. B., 1974, Vegetation management for increased water yield in Arizona: Arizona Univ., Agr. Expt. Sta. Tech. Bull 215, 38 p.

Green, C. R., and Sellers, W. D., eds., 1964, Arizona climate: Tucson, Arizona Univ. Press, 503 p.

Harshbarger, J. W., Lewis, D. D., Skibitzke, H. E., Heckler, W. L., and Kister, L. R., 1966, Arizona water: U.S. Geol. Survey Water-Supply paper $1648,85 \mathrm{p}$.

Hillel, Daniel, 1971, Soil and Water-Physical principles and processes: New York, Academic Press, 288 p.

Kelso, M. M., Martin, W. E., and Mack, L. E., 1973, Water supplies and economic growth in an arid environment-An Arizona case study: Tucson, Arizona Univ. Press, 327 p.

Kelso, M. M., and others, 1974, Economic implication of public water policy in Arizona: U.S. National Tech. Inf. Service PB 241 513, $133 \mathrm{p}$.

Kister, L. R., 1973, Quality of ground water in the lower Colorado River region, Arizona, Nevada, New Mexico, and Utah: U.S. Geol. Survey Hydrol. Inv. Atlas HA-478, 2 sheets.

Laney, L. J., 1972, Chemical quality of the water in the Tucson basin, Arizona: U.S. Geol. Survey Water-supply Paper 1939-D, 46 p.

Laverty, F. B., 1945, Correlating flood control and water supply-Los Angeles coastal plain: Am. Soc. Civil Engineers Proc., v. 71, no. 6 , p. $831-848$.

Levings, G. W., and Farrar, C. D., 1977a, Maps showing ground-water conditions in the Monument Valley and northern part of the Black Mesa areas, Navajo, Apache, and Coconino Counties, Arizona-1976: U.S. Geol. Survey Water-Resources Inv. 77-44, maps.

1977b, Maps showing ground-water conditions in the southern part of the Black Mesa area, Navajo, Apache, and Coconino Counties, Arizona-1976: U.S. Geol. Survey Water-Resources Inv. 77-41, maps.
$1977 \mathrm{c}$, Maps showing ground-water conditions in the southern part of the Chinle area, Apache County, Arizona-1976: U.S. Geol. Survey Water-Resources Inv. 77-50, maps.

Lofgren, B. E., 1968, Analysis of stresses causing land subsidence, in Geological survey research 1968: U.S. Geol. Survey Prof. Paper 600-B, P. B219-B225.

Lucas, Ken, 1975, Thanks to sprinklers, Yuma desert alive with wheat: Arizona Farmer-Ranchman, v. 54, no. 5, p. 24-25.

McGavock, E. H., and Edmonds, R. J., 1974, Availability of ground water for irrigation, municipal, or industrial use in the Navajo and Hopi Indian Reservations, Arizona, New Mexico, and Utah: U.S. Geol. Survey Misc. Inv. Ser. Map I-878, 4 sheets.

Mann, L. J., 1976, Ground-water resources and water use in southern Navajo County, Arizona: Arizona Water Comm. Bull. 10, 106 p.

1977, Maps showing ground-water conditions in the Puerco-Zuni area, Apache and Navajo Counties, Arizona-1975: U.S. Geol. Survey Water-Resources Inv. 77-5, maps.

Meyers, J. S., 1962, Evaporation from the 17 Western States: U.S. Geol. Survey Prof. Paper 272-D, 100 p.

MITRE Corporation, 1977, Annual environmental analysis report-An environmental analysis of energy technologies using the assumptions of the National Energy Plans-Volume 1, Technical summary: MITRE Corp. Rept., September.

Murray, C. R., and Reeves, E. B., 1972, Estimated use of water in the United States in 1970: U.S. Geol. Survey Circ. 676, $37 \mathrm{p}$.

National Academy of Sciences and National Academy of Engineering, 1973, Water quality criteria 1972: U.S. Environmental Protection Agency Rept. EPA-R3-73-033, 594 p.

Pacific Southwest Interagency Committee, 1971a, Lower Colorado Region Comprehensive Framework Study, Appendix IV, Economic base and projection for 1980, 2000, 2020: Pacific Southwest Interagency Comm. report, $181 \mathrm{p}$.

1971b, Lower Colorado Region Comprehensive Framework Study, Appendix V, Water resources: Pacific Southwest Interagency Comm. report, $115 \mathrm{p}$.

1971c, Lower Colorado Region Comprehensive Framework Study, Appendix XIV, Electric power: Pacific Southwest Interagency Comm. report, $144 \mathrm{p}$.

Penman, H. L., 1948, Natural evaporation from open water, bare soil, and grass: Royal Soc. London Proc., sec. A, v. 193, p. 120-145. 1956a, Estimating evaporation: Am. Geophys. Union Trans., v. 37 , no. 1 , p. $43-46$.

1956b, Evaporation, an introductory survey: Netherland Jour. Agricultural Science, v. 4, p. 9-29.

Poland, J. F., and Davis, G. H., 1969, Land subsidence due to withdrawal of fluids, in Varnes, D. J., and Kiersch, George, eds., Reviews in engineering geology-Volume 2: Boulder, Colo., Geol. Soc. America, p. 187-269.

Richter, R.C., and Chun, Y. D., 1959, Artificial recharge of groundwater reservoirs in California: Am. Soc. Civil Engineers Proc., Irrigation and Drainage Div. Jour., v. 85, no. IR4, p. 1-7.

Schumann, H. H., 1974, Land subsidence and earth fissures in alluvial deposits in the Phoenix area, Arizona: U.S. Geol. Survey Misc. Inv. Ser. Map I-845-H, 1 sheet.

Schumann, H. H., and Poland, J. F., 1970, Land subsidence, earth fissures, and groundwater withdrawal in south-central Arizona, U.S.A., in Land subsidence: Tokyo, Internat. Assoc. Sci. Hydrology Pub. 88, v. 1, p. 295-302.

Thornthwaite, C. W., 1948, An approach toward a rational classification of climate: Geog. Rev., v. 38, no. 1, p. 55-94.

Todd, D. K., 1959, Annotated bibliography on artificial recharge of ground water through 1954: U.S. Geol. Survey Water-Supply Paper 1477, $115 \mathrm{p}$. 
U.S. Bureau of Mines, 1974, Area reports-domestic, in Minerals yearbook, 1972, Volume II: U.S. Bur. Mines, 805 p.

U.S. Bureau of Reclamation, 1975, Compilation of records in accordance with Article $\mathrm{V}$ of the decree of the Supreme Court of the United States in Arizona v. California dated March 9, 1964: Boulder City, Nev., U.S. Bur. Reclamation, 40 p.

U.S. Geological Survey, 1971, Map showing the general depth to ground water in New Mexico: U.S. Geol. Survey open-file map.
Valley National Bank of Arizona, 1974, Arizona statistical review: Valley Natl. Bank of Arizona, 30th ann. ed., $70 \mathrm{p}$.

1975, Arizona statistical review: Valley Natl. Bank of Arizona, 31st ann. ed., $72 \mathrm{p}$.

Winograd, I. J., 1974, Radioactive waste storage in the arid zone: Am. Geophys. Union Trans., v. 55, no. 10, p. 884-894. 

